\title{
Water Productivity and Fruit Quality in Deficit Drip Irrigated Citrus Orchards
}

\author{
Ana Quiñones, Carolina Polo-Folgado, Ubaldo Chi-Bacab, \\ Belén Martínez-Alcántara and Francisco Legaz \\ Instituto Valenciano de Investigaciones Agrarias, Moncada (Valencia)
}

Spain

\section{Introduction}

Citrus is one of the most relevant crops worldwide with a yearly average production of $90 \cdot 10^{6} \mathrm{Mg}$ in the last decade. In Mediterranean countries, citrus is the second largest fruit crop after apples, in the European Union (EU). Spain is the leading producer in the area with nearly $60 \%$ of tonnes produced in the whole of the EU (Ollier et al., 2009). In Spain, citrus orchards cover around $300 \cdot 10^{3}$ ha $\left(6 \cdot 10^{6} \mathrm{Mg}\right)$ of which up to $60 \%$ is located in the Comunidad Valenciana (CV). This area has remained more or less constant in this respect since 1990 (MARM, 2010). The Comunidad Valenciana is the most important region, not only in acreage but also with respect to its long tradition of citrus farming.

In this area, like in many regions of the world, the lack of water or lack of good water is a growing concern for the development of relevant agriculture since water is the most limiting factor for crop production. Moreover, climatic conditions are characterized by low rainfall (400-600 mm year-1) and irregular spatial and temporal distribution. On the other hand, the world's population has undergone an exponential growth, which has led to soaring food demand and, therefore, high natural-resource exploitation. For example, in Spain, irrigated land had risen up to 3.421.304 ha in 2009 (MARM, 2010).

Therefore, improved water use efficiency (WUE) or water productiviy (WP), using different strategies, is a key concept to solve this water scarcity. So nowadays, efforts are being focussed on developing not only alternative irrigation methods but also new water management methods in order to reduce water dosages while maintaining maximum tree growth, without significantly affecting yield.

\section{Options for improving irrigation efficiency}

Wallace and Batchelor (1997) showed the main options for improving WUE in different categories, engineering, agronomy, management and institutional improvements. Although it is not possible to discuss all the options listed in detail by these authors, three of the options are of particular interest.

Concerning engineering improvements, there are several irrigation systems to water crops that can reduce application losses and improve application uniformity. 
In flood irrigation, a large amount of water is directed to the field and flows over the ground among the crops. In regions where water is abundant, flood irrigation is the cheapest irrigation method and this low tech irrigation method is commonly used in developing countries. On the contrary, localized irrigation is a system where water is distributed under low pressure through a piped network, in a pre-determined pattern, and applied as a small discharge to each plant or adjacent to it. Regarding irrigation systems, in the citrus area of Spain, about $69 \%$ of citrus orchards are irrigated under fertigation, mainly with drip irrigation, and the remaining by flood irrigation (MARM, 2010). Similar percentages are found in other citrus areas where localized (drip or mini-sprinklers) irrigation systems are mainly used for citrus and other tree crops (olives and deciduous trees), while sprinkler irrigation is dominant for fodder crops and some vegetables.

Depending on the different localized irrigation system fertigation can be performed on surface or subsurface drip, spray, micro-jet and micro-sprinkler. These different techniques can be used, both in annual crops or fruit trees, according to soil type and the different characteristics of agricultural area. This versatility has led to a rapid expansion of fertigation in the world cultivated areas. The advantages of fertigation are listed below (Burt et al, 1998).

- High water and nutrient use efficiency as a consequence of coupling fertilizer timing to the plant requirements and, therefore, minimized fertilizer/nutrient loss due to localized application and reduced leaching.

- $\quad$ Reduced energy cost by the saving of labour and machinery and the efficient use of the costly chemicals to be applied.

- $\quad$ Minimized soil erosion by avoiding heavy equipment traffic through the field to apply fertilizers.

Moreover, fertigation allows safe use of recycled or saline water. Boman et al., (2005) affirmed that irrigation scheduling is a key factor in managing salinity. Increasing irrigation frequency and applying water exceeding the crop requirement are recommended to leach the salts and minimize their concentration in the root zone. Fertigation also reduces the risk of diseases since foliage remains dry. Schumann et al., (2009) observed a significant reduction in the number infected trees of citrus greening disease or citrus canker by optimising daily and nutrient levels for trees. Moreover, frequent and small water split with fertigation technique leads to a shallow and compact root system in comparison with a wide and deeper root system in flood irrigated trees (Sne, 2006), enhances $\mathrm{N}$ uptake efficiency by the fibrous roots and contributes to lower leaching below the root zone (Quiñones et al., 2007).

In drip irrigation systems, subsurface drip irrigation (SDrI) has been part of modern agriculture. Current commercial and grower interest levels indicate that future use of SDrI systems will continue to increase. SDrI applies water below the soil surface, using buried drip tapes (ASAE, 2001). SDrI uses buried lateral pipelines and emitters to apply water directly to the plant root zone. Laterals are placed deep enough to avoid damage by normal tillage operations, but sufficiently shallow so that water is redistributed in the active crop root zone by capillarity. SDrI systems must be compatible with the total farming and cultural systems being used.

SDrI requires the highest level of management of all microirrigation systems to avoid remedial maintenance. A poorly designed SDrI system is much less forgiving than an 
improperly designed surface drip system. Deficiencies and water distribution problems are difficult and expensive to remedy. Lamm and Camp (2007) present an excellent, detailed review of SDrI.

These systems require safeguards and special operational procedures to prevent plugging and facilitate maintenance, but they also have numerous advantages. These were:

- The top of the soil surface remains dry, limiting surface evaporation to the rate of vapour diffusion transport and preventing salt accumulations on the surface.

- The use of a very high irrigation frequency (several times per day) that matches actual crop water use will result in a constant wetted soil volume and a net upward hydraulic gradient, which minimizes leaching.

- Supplying water and nutrients directly to the root zone allows root uptake to be more efficient if irrigation and fertilization schedules are appropriate.

- Soil crusts, which may impede infiltration and cause ponding and runoff, are bypassed so that surface infiltration variability becomes insignificant.

Under proper management, appropriately designed and managed SDI irrigation systems offer several other advantages to growers (Devasirvatham, 2009) because of their potential for:

- Maintaining access to fields with tillage, planting, spray and harvest equipment that is not restricted by irrigation.

- Obtaining better weed suppression with minimal chemicals because there is less seed germination with dry soil surfaces.

- $\quad$ Efficiently and safely applying labelled plant-systemic pesticides and soil fumigants for improved disease and pest control.

- $\quad$ Reducing surface wetting often reduces fungal disease incidence (e.g., molds, mildews) by maintaining dryer plant surfaces and lower air humidity within the plant canopy.

- $\quad$ Reducing pesticide exposures for workers when chemicals are applied below the soil surface.

- Implementing minimum tillage, permanent beds, and multiple cropping systems (Bucks et al., 1981), although much of the necessary equipment modifications and farming techniques have yet to be developed; and minimizing flow-rate sensitivity to temperature fluctuations because emitters are buffered by the soil.

Phene et al. (1992) and Phene (1995) listed several drawbacks, including potentially high initial system costs, potential rodent damage, the fact salt may accumulate between drip lines and soil surface, low upward water movement in coarse-textured soils, high potential for emitter plugging, and insufficient technical knowledge requiring dissemination, and hands-on experience by growers and researchers. In addition, fertility management becomes more critical with SDI because roots tend to grow deeper than with surface drip systems and some surface applied nutrients may not be sufficiently available (Phene, 1995).

Improved WUE can also be affected by water regimes. Although WUE frequently decreases under water deficit conditions (García Tejero et al. 2011), in areas with significant water scarcity, like in the east of Spain, it is possible to increase efficiency under different irrigation management methods based on deficit-irrigation (DI) programmes (Bonet et al. 2010). These DI strategies are defined as a practise where the total water provided for the plant 
(irrigation plus effective rainfall) is below to the crop's water needs (García-Tejero, 2010) in order to reduce ETc, and hence save water, while simultaneously minimizing or eliminating negative impacts of stress on fruit yield or quality. This approach differs from season-long stress in that the deficit irrigation is restricted to stress-tolerant periods. Essentially, there are two methods to achieve DI management of a crop, reducing the amount of water supplied or increasing the period between irrigation cycles.

Regarding reducing the quantity of water applied, Sustained DI (SDI) and Regulated DI (RDI) are the most widely used practices in several tree crops. SDI is when a reduced percentage of ETc is applied throughout the irrigation season without considering its phenological period or the accumulated water stress. Regulated deficit irrigation (RDI) is based on supplying some $100 \%$ of ETc when the crop is less tolerant to water stress and a reduced percentage for the rest of the season. The water stress tolerated by the crops is closely related to crop phenology and, therefore, a detailed knowledge on tree physiology is crucial for successful use of RDI. Deficit irrigation strategies are not recommended for young orchards, since conditions must be favoured under which trees reach maturity as soon as possible.

Concerning the methods based on increasing periods between irrigation events, Low frequency DI (LFDI) is when the soil is left to dry until the readily available water is consumed; then the soil is irrigated to field capacity and left to dry again. Under this strategy the crop is kept below a certain water stress threshold value (García-Tejero, 2010).

Options for enhancing irrigation efficiency in the agronomic category are related to crop management. Different strategies to improve rainfall use or reduce evaporation can be performed. In this respect, it is important to note that precipitation is not a reliable water source, but can contribute to some degree towards water needs. Therefore, usable rainfall or effective precipitation, which is the portion of total precipitation retained by soil available for plants, must be calculated in the water plant requirements.

The research reported here summarizes the results obtained in terms of the response of yield, fruit quality and nutritional tree status in citrus orchards under two irrigation systems, three deficit irrigation strategies and two effective precipitation values during five consecutive seasons (2006-2010). Also, the benefits of each irrigation strategy were estimated in terms of agricultural water productivity (WPagr).

\section{Design factors}

The different experimental plots were located in Puzol, Valencia (latitude $39^{\circ} 34^{\prime} \mathrm{N}$; longitude $00^{\circ} 24^{\prime} \mathrm{W}$, elevation $25 \mathrm{~m}$ ) in the East of Spain, in commercial orchards of clementine cv. Nules mandarin adult trees (Citrus clementine Hort. Tanaka x C. reticulata Blanco) grafted onto citrange Carrizo rootstock [C. sinensis L. (Osb.) x Poncirus trifoliata L.(Raff.)], planted at a spacing of $3.5 \mathrm{~m} \times 5.6 \mathrm{~m}$ (i.e. 510 trees ha-1). This variety, grafted onto Carrizo citrange is highly representative in the study area, this being the most widely used rootstock in citrus orchards in the Comunidad Valenciana area (MARM, 2010).

\subsection{Soil and water characteristics}

The trees were grown on Cambic Arenosol soil (62.6\% sand, 19.2\% silt, 18.2\% clay; $\mathrm{pH} 8.2$; organic matter content $1.03 \%$ and a bulk density of $1.6 \mathrm{~kg} \mathrm{~m}^{-3}$ ) with low water holding capacity $(16 \%)$. 
The irrigation water had an average electrical conductivity of $2.8 \mathrm{mS} \mathrm{cm}-1$, containing an annual average of 272, 212 and $100 \mathrm{mg} \mathrm{L}^{-1}$ of $\mathrm{NO}_{3}{ }^{-}, \mathrm{Ca}^{2+}$ and $\mathrm{Mg}^{2+}$, respectively.

\subsection{Climatic conditions}

The general climatic conditions for the experimental sites is Mediterranean dry, with an average potential evapotranspiration (ET0) close to $1500 \mathrm{~mm} \mathrm{yr}^{-1}$, and annual rainfall between 250 and $500 \mathrm{~mm} \mathrm{yr}^{-1}$, with a high monthly variability distributed mainly from October to May. The thermal range is broad, with mild temperatures in winter, rarely below $0 \circ \mathrm{C}$ and severe conditions in summer, with temperatures in many cases exceeding $40 \circ \mathrm{C}$. These environmental conditions promote an average annual water deficit of around $1000 \mathrm{~mm}$.

\subsection{Fertilization program}

The nutrient-fertilizer rate and seasonal distribution for citrus plants was calculated for a $3.10 \mathrm{~m}$ canopy diameter in citrus trees grown under drip irrigation. Nitrogen $(\mathrm{N})$ requirements were $400 \mathrm{~g} \mathrm{~N}$ tree $^{-1}$ year-1 based on Legaz and Primo-Millo (1988), of which an average value of 58 and $49 \%$ were supplied as potassium nitrate in 50 and $100 \%$ canopy area coefficients of effective precipitation in UEP (use of effective precipitation) treatments, respectively. These coefficients were arbitrarily chosen. The $\mathrm{N}$-remainder was provided by typical irrigation water in the Mediterranean area, with $272 \mathrm{ppm}$ of nitrate concentration, as described above. The quantity of $\mathrm{N}$ contributed by the irrigation water was calculated using the formula described by Martinez et al., (2002). Phosphorus and potassium fertilizer demand was $120 \mathrm{~g} \mathrm{P}_{2} \mathrm{O}_{5}$ tree-year $^{-1}$ applied as phosphoric acid $\left(48 \% \mathrm{P}_{2} \mathrm{O}_{5}\right)$ and $475 \mathrm{~g} \mathrm{~K}_{2} \mathrm{O}$ tree-year ${ }^{-1}$ applied as potassium nitrate $\left(44 \% \mathrm{~K}_{2} \mathrm{O}\right.$ equivalent). The basic iron needs per tree were distributed throughout the growing cycle in a similar way for N. Foliar spray treatments of zinc $(\mathrm{Zn})$ and manganese $(\mathrm{Mn})$ were applied as organic commercial fertilizer at $0.5 \%$ weight $(\mathrm{w}) /$ volume(v) (Zn: $6.6 \% \mathrm{w} / \mathrm{w}$ and $\mathrm{Mn}: 4.8 \% \mathrm{w} / \mathrm{w})$ to correct deficiencies.

\subsection{Irrigation scheduling}

The amount of water applied to each tree was equivalent to the total seasonal crop evapotranspiration (ETc) calculated using the formula described by Aboukhaled et al. (1982).

$$
\operatorname{ETc}(\mathrm{mm})=\frac{\operatorname{ETo}(\mathrm{mm})}{\mathrm{Kc}}
$$

Where ETo is the reference crop evapo-transpiration under standard conditions and $\mathrm{Kc}$ is the crop coefficient (Table 1). This coefficient (Kc per month) accounts for crop-specific effects on overall crop water requirements and is a function of canopy size and leaf properties. The ETo values were determined using the Penman-Monteith approach (Allen et al. 1998) using hourly data collected by an automated weather station situated near the orchard The values obtained were 1108, 1041, 972, 1043 and $1092 \mathrm{~mm} \mathrm{yr}^{-1}$ in 2006, 2007, 2008, 2009 and 2010 respectively. The Kc values were based on guidelines provided by Castel and Buj (1994). Irrigation water requirements were met by the effective rainfall ( $\geq 3 \mathrm{~mm}$ and $\leq 45$ 
$\mathrm{mm}$ which resulted in soil water saturation) of the entire year plus irrigation water for the three years of the assay, respectively). The annual rainfall was 315, 516, 463, 472 and $392 \mathrm{~mm}$ $\mathrm{yr}^{-1}$ in 2006 to 2010, respectively.

There is scarcely any information about the use of rainfall by crops, possibly due to the difficulty of evaluation. In this research study, rainfall was recorded as the mean of three rain gauges placed in different parts of the orchard. Irrigation water requirements covered by effective precipitation (UPe) were calculated according to the following expression:

$$
\text { UPe }\left(\mathrm{m}^{3} \text { tree }^{-1}\right)=\mathrm{CA}\left(\mathrm{m}^{2}\right) \times \mathrm{Pe}\left(\mathrm{L} \mathrm{m}^{-2}\right) \times \mathrm{F} \times 0.001\left(\mathrm{~L} \mathrm{~m}^{-3}\right)
$$

Where CA is canopy area of the tree at the beginning of each growth cycle, Pe is effective precipitation corresponding to rainfall greater than $3 \mathrm{~mm}$ (lower values are not utilizable by the plant) and less than $33 \mathrm{~mm}$ (which saturate the soil profile and water percolates through soil to groundwater), $\mathrm{F}$ is the potential factor for effective precipitation use (0.5 or 1$)$.

\begin{tabular}{ccccccccccccc}
\hline Month & Jan & Feb & Mar & Apr & May & Jun & Jul & Aug & Sep & Oct & Nov & Dec \\
\hline $\begin{array}{l}\text { Factor } \\
\text { Kc per }\end{array}$ & 0.97 & 0.96 & 0.97 & 0.91 & 0.81 & 0.91 & 1.00 & 1.16 & 1.09 & 1.24 & 1.07 & 0.93 \\
month & 0.505 & 0.500 & 0.505 & 0.474 & 0.422 & 0.474 & 0.521 & 0.604 & 0.567 & 0.646 & 0.557 & 0.484 \\
\hline
\end{tabular}

Table 1. Month crop coefficient $(\mathrm{Kc})=$ Factor $\mathrm{x}$ Kc mean $(0.521)$

Trees were surface and subsurface drip-irrigated, through eight pressure-compensating emitters $\left(4 \mathrm{~L} \mathrm{~h}^{-1}\right.$ each) per tree, placed every $88 \mathrm{~cm}$ in two drip lines, and at a depth of $30 \mathrm{~cm}$ in subsurface drip irrigated trees, both located within $100 \mathrm{~cm}$ of the tree trunk and producing a 33\% wetted area (Keller and Karmelli, 1974). Moreover, plants were fertirrigated from 0 to 3 times per week, according to evapotranspiration demand and effective rainfall.

\subsection{Experimental design}

The assay treatments consisted of two irrigation systems, three regulated deficit irrigation practices and two effective precipitation coefficients. The combinations of these factors resulted in twelve treatments distributed in a randomised complete block design and with three replicates each, and fifty trees per plot (Table 2).

Irrigation treatments were subsurface drip irrigation (SDrI) and drip irrigation (DrI). Regulated deficit irrigation practices were:

i. Control fully irrigated trees where irrigation scheduling was based on the standard FAO approach replacing crop as described above. Therefore, $100 \%$ of crop evapotranspiration (ETc) was covered during the whole year (100\% treatments)

ii. Standard regulated deficit irrigation $\left(\mathrm{RDI}_{70}\right)$ where water was applied at $70 \%$ of ETc during July (at the beginning of fruit growth) to the end of October (post-harvest). During the rest of the season water was applied at $100 \%$ of ETc.

iii. Alternate regulated deficit irrigation $\left(\mathrm{RDI}_{100-40}\right)$ where water was applied at $100-40 \%$ alternate irrigation events of ETc during the same period explained above. Similarly, during the rest of the season water was applied at $100 \%$ of ETc. 
To calculate the portion of total precipitation used by the plants (use of effective precipitation); two coefficients of effective precipitation (UEP) were arbitrarily employed, corresponding to 50 and $100 \% \%$ canopy area (\% CA).

\begin{tabular}{ccccc}
\hline Treatments & Irrigation system $^{1}$ & $\begin{array}{c}\text { ETc } \\
{[\%]^{2}}\end{array}$ & $\begin{array}{c}\text { UPe } \\
{[\% \mathrm{CA}]^{3}}\end{array}$ & $\begin{array}{c}\text { Tree } \\
\text { Treament }^{-1}\end{array}$ \\
\hline DrI $_{100-50}$ & DrI & 100 & 50 & 54 \\
SDrI $_{100-50}$ & SDrI & 100 & 50 & 51 \\
DrI $_{70-50}$ & DrI & $100-70$ & 50 & 51 \\
SDrI $_{70-50}$ & SDrI & $100-70$ & 50 & 54 \\
DrI $_{100 / 40-50}$ & DrI & $100-100 / 40$ & 50 & 54 \\
SDrI $_{100 / 40-50}$ & SDrI & $100-100 / 40$ & 50 & 51 \\
DrI $_{100-100}$ & DrI & 100 & 100 & 51 \\
SDrI $_{100-100}$ & SDrI & 100 & 100 & 54 \\
DrI $_{70-100}$ & DrI & $100-70$ & 100 & 54 \\
SDrI $_{70-100}$ & SDrI & $100-70$ & 100 & 51 \\
DrI $_{100 / 40-1000}$ & DrI & $100-100 / 40$ & 100 & 51 \\
SDrI $_{100 / 40-100}$ & SDrI & $100-100 / 40$ & 100 & 54 \\
\hline
\end{tabular}

Table 2. Treatments performed during 2006-2009. 1:Irrigation system, DrI: Drip irrigation, SDrI: Subsurface Drip irrigation; ${ }^{2}$ :Regulated deficit irrigation, 100, 70 and 100-40 \% of crop evapotranspiration (ETc). 3:Use of effective precipitation

\subsection{Sample collection and measurements}

Spring-flush leaves from non-fruiting shoots (around 10 leaves per tree) were randomly sampled in November, from around the canopy. Then, leaves were frozen in liquid- $\mathrm{N}_{2}$ and freeze-dried (lyophilised). Samples were ground with a water-refrigerated mill, then sieved through a $0.3 \mathrm{~mm}$ mesh sieve and stored at $-20{ }^{\circ} \mathrm{C}$ for further analysis, no more than one month later.

Macro and micronutrient concentration was measured to test nutritional status of the tree and quantify annual nutrient requirements of a crop. Total nitrogen content of spring flush leaves was determined using an Elemental Analyser (NC2500 Thermo Finnigan, Bremen, Germany). Other macronutrients were measured by simultaneous ICP emission spectrometry (iCAP-AES 6000, Thermo Scientific. Cambridge, United Kingdom). Results were expressed as a percentage of dry weight (DW).

In November of each year $\left(19^{\text {th }}, 17^{\text {th }}\right.$ and $22^{\text {nd }}$ of November in the $1^{\text {st }}, 2^{\text {nd }}$ and $3^{\text {rd }}$ year of the assay), which is the commercial harvest period, the yields of all replicates of each treatment were weighed and a representative sample of forty fruits per replication (5 fruits per tree from 8 trees per replication) was collected at random, weighed and internal fruit quality (including fruit weight, fruit diameter, peel thickness, peel and juice weight, total soluble-solids content, total acidity and colour index) was measured. The number of fruits was calculated using the ratio of yield to average weight of individual fruit. Fruit weight, peel and juice content were determined gravimetrically. Equatorial fruit diameter of samples was measured for each fruit using a digital calliper (Mitutoyo CD-15D, Japan) and the average value of the sample was calculated. Total soluble solids (TSS) content of 
juice ('Brix) was measured using a digital refractometer (Atago PR-101 Alfa, Tokyo, Japan) and total acidity (TA) was assessed by titration with $0.1 \mathrm{~N} \mathrm{NaOH}$, using phenolphthalein as indicator. The ratio between TSS and TA, commonly called maturity index, was calculated. Colour index $(\mathrm{CI})$ was measured taking three readings around the equatorial surface of each fruit using a Minolta Chroma Meter CR-300 (Minolta Camera Co. Ltd., Osaka, Japan). The results are given in the Hunter Lab Colour Scale. This system is based on $L, a$ and $b$ measurements. The $L$ values represent light from zero (black) to 100 (white). The $a$ values change from $-a$ (greenness) to $+a$ (redness), while the $b$ value is from $-\mathrm{b}$ (blueness) to $+\mathrm{b}$ (yellowness). From $L, a$ and $b$ values, a ratio of $1000 \mathrm{a} / \mathrm{L} \cdot \mathrm{b}$ is calculated to give the citrus colour index (Ladaniya, 2008).

In addition, impact of different irrigation scheduling on agricultural water productivity (WP) was evaluated, taking into account the water applied, through a ratio between the crop yield $(\mathrm{kg})$, and the total water applied:

$$
\mathrm{WP}\left(\mathrm{kg} \mathrm{m}^{-3}\right)=\frac{\text { Yield }}{\text { irrigation }+ \text { rain }}
$$

\subsection{Statistical analyses}

Data are summarized in tables as means from three replicates \pm standard errors. All data were statistically analysed using PROC ANOVA (SAS version 9, SAS Institute, Cary, NC, USA) and least significant difference multiple range-tests were used to identify differences among the means of the parameters examined. Significance was considered at $P<0.05$.

\section{Water saving irrigation response to water management strategies}

The annual volumes of ETc covered by irrigation water and effective rainfall are shown in Table 3 for both irrigation systems (DrI and SdrI). The percentages of water irrigation savings due to the contribution of UPe and RDI strategies are also presented.

Regarding effective precipitation use percentage (50 or $100 \% \mathrm{CA}$ ), the reduction in irrigation water applied was significantly higher when $100 \%$ canopy area (an average over $36 \%)$ was considered than for $50 \%$ canopy area (20\%) in all the years tested. Moreover, significant differences between years were observed, with higher water saving in 2007, 2008 and 2009 (an average over $30 \%$ ) than in 2006 (20\%), due to increased rainfall volume during those years.

Concerning regulated deficit irrigation (RDI) strategies, the reduction of 100 to 70 (or 100-40 $\%$ ETc alternate irrigation event) in the percentage of ETc covered by irrigation water allowed a significant water irrigation saving of up to $16 \%$, without significant differences between deficit water management. In this parameter, significant differences among years were also recorded, with a lower irrigation saving in 2008 corresponding to the lower ETc. The coefficient used when calculating rainfall water use did not affect this variable.

The overall saving of irrigation water due to both UEP and RDI strategies maintained a similar trend to that described for the previous variable. The greatest savings were obtained using a coefficient of $100 \%$ CA with RDI management in 2007, achieving a $66 \%$ reduction in the irrigation water supplied of (DrI $\mathrm{D}_{70-100} / \mathrm{SDrI}_{70-100}$ and $\mathrm{DrI}_{100 / 40-100} / \mathrm{SDrI}_{100 / 40-100}$ treatments) 


\begin{tabular}{|c|c|c|c|c|c|c|c|}
\hline \multirow[t]{2}{*}{ Year } & \multirow[t]{2}{*}{ Treatments } & \multicolumn{3}{|c|}{ ETc covered by $\left(\mathrm{m}^{3}\right.$ ha-year-1) } & \multicolumn{3}{|c|}{$\begin{array}{l}\text { Reduction in irrigation water by } \\
(\%)\end{array}$} \\
\hline & & UPe & IW & $\mathrm{UPe}+\mathrm{IW}$ & UEP & RDI & $\mathrm{UEP}+\mathrm{RDI}$ \\
\hline \multirow[t]{6}{*}{2006} & $\operatorname{DrI}_{100-50} / \mathrm{SDrI}_{100-50}$ & 853 & 4928 & 5781 & 14,76 & 0,00 & 14,76 \\
\hline & $\operatorname{DrI}_{70-50 /} \mathrm{SDrI}_{70-50}$ & 853 & 3903 & 4756 & 14,76 & 17,73 & 32,49 \\
\hline & $\operatorname{DrI}_{100 / 40-50 / S D r I}{ }_{100 / 40-50}$ & 853 & 3898 & 4751 & 14,76 & 17,82 & 32,57 \\
\hline & $\operatorname{DrI}_{100-100 /}$ SDrI $_{100-100}$ & 1485 & 4256 & 5741 & 25,87 & 0,00 & 25,87 \\
\hline & $\operatorname{DrI}_{70-100} /$ SDrI $_{70-100}$ & 1485 & 3282 & 4767 & 25,87 & 16,97 & 42,83 \\
\hline & $\operatorname{DrI}_{100 / 40-100} / \mathrm{SDrI}_{100 / 40-100}$ & 1485 & 3279 & 4764 & 25,87 & 17,02 & 42,88 \\
\hline \multirow[t]{6}{*}{2007} & $\mathrm{DrI}_{100-50} / \mathrm{SDrI}_{100-50}$ & 1230 & 4204 & 5434 & 22,64 & 0,00 & 22,64 \\
\hline & $\operatorname{DrI}_{70-50 /} \mathrm{SDrI}_{70-50}$ & 1230 & 3245 & 4475 & 22,64 & 17,65 & 40,28 \\
\hline & $\operatorname{DrI}_{100 / 40-50 / S D r I}{ }_{100 / 40-50}$ & 1230 & 3219 & 4449 & 22,64 & 18,13 & 40,76 \\
\hline & $\operatorname{DrI}_{100-100 /} \mathrm{SDrI}_{100-100}$ & 2337 & 3011 & 5348 & 43,70 & 0,00 & 43,70 \\
\hline & $\operatorname{DrI}_{70-100} / \mathrm{SDrI}_{70-100}$ & 2337 & 1995 & 4332 & 43,70 & 19,00 & 62,70 \\
\hline & $\operatorname{DrI}_{100 / 40-100} / \mathrm{SDrI}_{100 / 40-100}$ & 2337 & 2008 & 4345 & 43,70 & 18,75 & 62,45 \\
\hline \multirow[t]{6}{*}{2008} & $\operatorname{DrI}_{100-50} / \mathrm{SDrI}_{100-50}$ & 1141 & 3788 & 4929 & 23,15 & 0,00 & 23,15 \\
\hline & $\operatorname{DrI}_{70-50 /} \mathrm{SDrI}_{70-50}$ & 1141 & 3313 & 4454 & 23,15 & 9,64 & 32,79 \\
\hline & $\operatorname{DrI}_{100 / 40-50 /} \mathrm{SDrI}_{100 / 40-50}$ & 1141 & 3332 & 4473 & 23,15 & 9,25 & 32,40 \\
\hline & $\operatorname{DrI}_{100-100 /} \mathrm{SDrI}_{100-100}$ & 2030 & 3244 & 5274 & 38,49 & 0,00 & 38,49 \\
\hline & DrI $_{70-100} / \mathrm{SDrI}_{70-100}$ & 2030 & 2689 & 4719 & 38,49 & 10,52 & 49,01 \\
\hline & $\operatorname{DrI}_{100 / 40-100} / \mathrm{SDrI}_{100 / 40-100}$ & 2030 & 2712 & 4742 & 38,49 & 10,09 & 48,58 \\
\hline \multirow[t]{6}{*}{2009} & $\operatorname{DrI}_{100-50} / \mathrm{SDrI}_{100-50}$ & 1136 & 4266 & 5402 & 21,03 & 0,00 & 21,03 \\
\hline & $\operatorname{DrI}_{70-50 /} \mathrm{SDrI}_{70-50}$ & 1136 & 3307 & 4443 & 21,03 & 17,75 & 38,78 \\
\hline & $\operatorname{DrI}_{100 / 40-50 / S D r I}{ }_{100 / 40-50}$ & 1136 & 3292 & 4428 & 21,03 & 18,03 & 39,06 \\
\hline & $\operatorname{DrI}_{100-100 /} \mathrm{SDrI}_{100-100}$ & 2214 & 3350 & 5564 & 39,79 & 0,00 & 39,79 \\
\hline & DrI70-100 /SDrI70-100 & 2214 & 2511 & 4725 & 39,79 & 15,08 & 54,87 \\
\hline & $\operatorname{DrI}_{100 / 40-100} / \mathrm{SDrI}_{100 / 40-100}$ & 2214 & 2507 & 4721 & 39,79 & 15,15 & 54,94 \\
\hline \multirow[t]{6}{*}{2010} & $\mathrm{DrI}_{100-50} / \mathrm{SDrI}_{100-50}$ & 1072 & 4950 & 6022 & 17,80 & 0,00 & 17,80 \\
\hline & DrI70-50/ SDrI70-50 & 1072 & 3848 & 4920 & 17,80 & 18,30 & 36,10 \\
\hline & $\operatorname{DrI}_{100 / 40-50 /} \mathrm{SDrI}_{100 / 40-50}$ & 1072 & 3849 & 4921 & 17,80 & 18,28 & 36,08 \\
\hline & $\mathrm{DrI}_{100-100 /} \mathrm{SDrI}_{100-100}$ & 2143 & 3836 & 5979 & 35,84 & 0,00 & 35,84 \\
\hline & DrI $_{70-100} /$ SDrI $_{70-100}$ & 2143 & 2703 & 4846 & 35,84 & 18,95 & 54,79 \\
\hline & $\operatorname{DrI}_{100 / 40-100} / \mathrm{SDrI}_{100 / 40-100}$ & 2143 & 2693 & 4836 & 35,84 & 19,12 & 54,96 \\
\hline \multirow[t]{6}{*}{ ANO } & $\mathrm{RDI}^{6}$ & & & & & $* * *$ & $* * *$ \\
\hline & $\mathrm{UEP}^{7}$ & & & & $* * *$ & NS & $* * *$ \\
\hline & Year & & & & * & $* * *$ & $* * *$ \\
\hline & RDI $x$ UEP & & & & & NS & NS \\
\hline & RDI $x$ Year & & & & & NS & NS \\
\hline & UEPxYear & & & & NS & NS & NS \\
\hline
\end{tabular}

Table 3. Water irrigation saving response to different irrigation strategies. UPe: volume of rainfall water available to the root system. IW: irrigation water applied. ${ }^{5}$ ANOVA: Significant effects of different irrigation strategies are given at $\mathrm{P}>0,05$ (NS, not significant ), $\mathrm{P} \leq 0,05\left(^{*}\right), \mathrm{P} \leq 0,01\left({ }^{* *}\right), \mathrm{P} \leq 0,001\left({ }^{* *}\right) .{ }^{6} \mathrm{RDI}$ : Regulated deficit irrigation (Control, 70 and 100-40 \% ETc). 7 UEP: coefficient use in effective precipitation (50 and $100 \%$ CA). 
By using regulated deficit irrigation (RDI) strategies, savings in irrigation water were recorded in peach orchards without reducing yield (Mitchell and Chalmers, 1982). Citrus has also been studied under deficit irrigation strategies. Thus, deficit irrigation treatments compared with the control, drip irrigated by six pressure compensated emitters per tree, allowed seasonal water savings of between 12 and 18\% (Velez et al., 2007). Similarly, experiments with RDI have been successful in citrus (Domingo et al. 1996; GonzálezAltozano and Castel, 1999; Goldhamer and Salinas, 2000). Similar results were reported for almond (Goldhamer et al., 2000), apple (Ebel et al., 1995), apricot (Ruiz-Sánchez et al., 2000), pear (Mitchell et al., 1989), pistachio (Goldhamer and Beede, 2004), wine grape vines (Bravdo and Naor, 1996; McCarthy et al., 2002), and olive (Moriana et al., 2003; Fernández et al., 2006). Accordingly, Fereres and Soriano (2007) published a comprehensive review on the use of deficit irrigation techniques to reduce water use in agriculture. However, there is no available information on the different UEP factor effects on water irrigation savings.

\section{Impact of water irrigation techniques on tree nutritional status}

Regarding macronutrient and micronutrient concentration in the spring flush leaves, significant differences were observed resulting from seasonality in most of the nutrients analysed (Table 4). However, every year, values were within the range considered optimal according to the standards described by Emblenton et al. (1973) and Legaz and Primo-Millo (1988). Only, Mg concentration showed slightly higher values due to the high concentration of this element in the irrigation water.

Regarding different factor effects (IS, RDI and UEP), foliar concentrations did not differ significantly between treatments. However, several authors found a higher foliar concentration in trees under SDrI than that obtained in DrI (Chartzoulakis and Bertaki, 2001). This indicates that this irrigation system improved nutrient absorption.

\section{Fruit yield and $\mathbf{W} \mathbf{P}_{\text {agr }}$ response to irrigation strategies}

Yield, expressed in $\mathrm{kg}$, and fruit number per tree, fruit weight and others fruit quality parameters are shown in Tables 5 to 7 . Season was observed to exert a significant effect on yield and fruit number parameters per tree (Table 1), with an evident alternate bearing pattern of trees during the assay, with years of low production and fruit number and high fruit weight ('off year') followed by years of high yield ('on year'). Similar results were also observed by other authors. Accordingly, El-Otmani et al. (2004) and Quiñones et al. (2011), among others, concluded that 'Nules' clementine mandarin is a cultivar with an alternatebearing pattern and poor fruit-set with a large number of small-sized fruits during the 'on year' crop mainly.

According to the irrigation system, this factor significantly affected the yield, number of fruits per tree and percentage of fruits in the first category $(>78 \mathrm{~mm})$. These variables were significantly lower under drip irrigation (DrI) than in subsurface irrigated trees (SDrI). In this regard, conflicting results have been found in the literature. A broad range of yield increases have been observed under SDrI when compared to surface, sprinkler, and even surface drip irrigation systems ranging from small to up to over $100 \%$ differences. Velez et al. (2007) in clementina de Nules mandarin subjected to different deficit irrigation observed, in two years of assay, that the deficit irrigation applied did not significantly reduce yield, 
nor average fruit weight compared with the control treatment. Besides there were no significant differences in fruit distribution by commercial sizes. The number of fruit harvested did not also vary between treatments, indicating that there were not carry over effects of the deficit irrigation applied. Research into SDrI has also been reported on crops including alfalfa (Oron et al., 1989; Bui and Osgood, 1990), asparagus (Sterret et al., 1990), cabbage and zucchini (Rubeiz et al., 1989), cantaloupe (Phene et al., 1987), cotton (Hutmacher et al., 1995) and tomatoes (Bogle et al., 1989), potatoes (Bisconer, 1987). Most yield increases have been attributed to better fertilization, better water management, improved water distribution uniformities, and improved disease and pest control. Grattan et al. (1988) cited better weed control as the major factor in the yield increases observed in their study. However, Yazar et al. (2002) obtained similar yield results for both irrigation methods in cotton. Brilay et al. (2003) also found a similar yield and fruit size in peach trees irrigated under drip and subsurface drip irrigation. In annual crops, like melon, surface drip irrigated plants yielded a higher percentage of 'first' category fruit along with greater equatorial diameter fruit compared to other treatments (Antunez et al. 2011).

Regarding deficit irrigation strategies, water stress significantly affected fruit weight and the percentage of fruit with a high calliper (up to $58 \mathrm{~mm}$ ). Control trees with a $100 \%$ ETc covered by irrigation water had significantly higher fruit weight and calliper than those irrigated under deficit regimes. Furthermore, these variables significantly increased with UEP when the latter rose from 50 to $100 \%$ CA. In citrus, Ginestar and Castel (1996) also observed a decrease in production, although not significant, as the amount of irrigation water was reduced in Nules clementine. In almond, Goldhamer et al. (2006) analysed the impact of three different water stress timing patterns. The most successful stress timing pattern in terms of yield (considering fruit size and load) was the pattern that imposed sustained deficit irrigation by applying water at a given percentage of full ETc throughout the season. Furthermore, Romero et al. (2004) analysed the influence of several RDI strategies under subsurface and surface drip irrigation. Thus, RDI, with severe irrigation deprivation during kernel-filling ( $20 \%$ ETc) and a post-harvest recovery at $75 \%$ ETc or up to $50 \%$ ETc under subsurface drip irrigation, may be adequate in almonds under semiarid conditions, saving a significant amount of irrigation water. Deficit irrigation effects on yield and vegetative development have also been analysed for drip irrigated olives. Thus, some authors (Tognetti et al., 2006) determined that water availability might affect fruit weight before flowering or during the early stages of fruit growth rather than later in the summer season. Thus, irrigation of olive trees with drip systems from the beginning of pit hardening may be recommendable. Comparing different treatments, deficit irrigation during the whole summer resulted in improved plant water relations with respect to other watering regimes, while severe RDI differentiated treatments only slightly from rain fed plants (Tognetti et al., 2005).

A joint assessment of the effects of different irrigation strategies based exclusively on yield and water savings is difficult because crop response depends not only on irrigation, but also on climate, soil, cultivar, age, etc. In this sense, WP enables comparisons to be made incorporating all the data, thus establishing the most effective irrigation strategy (GarciaTejero et al., 2011).

In this assay, the different strategies significantly affected WP values. Regarding the irrigation system, SDrI resulted in significantly higher water efficiency than that obtained with DrI. This result could be due to the fact that subsurface drip systems may further 


\begin{tabular}{|c|c|c|c|c|c|c|c|c|c|c|c|c|c|}
\hline Year & Treatments & $\mathrm{N}$ & $\mathrm{P}$ & K & $\mathrm{Ca}$ & $\mathrm{Mg}$ & S & $\mathrm{Na}$ & B & $\mathrm{Fe}$ & Mn & $\mathrm{Zn}$ & $\mathrm{Cu}$ \\
\hline \multirow[t]{12}{*}{2007} & DrI $_{100-50}$ & 2.02 & 0.109 & 0.47 & 3.51 & 0.45 & 0.254 & 0.059 & 58.3 & 62.3 & 22.4 & 24.4 & 4.13 \\
\hline & $\mathrm{SDrI}_{100-50}$ & 2.04 & 0.119 & 0.50 & 3.75 & 0.46 & 0.267 & 0.053 & 59.2 & 63.9 & 25.4 & 26.2 & 4.80 \\
\hline & $\operatorname{DrI}_{70-50}$ & 2.02 & 0.106 & 0.48 & 3.28 & 0.42 & 0.236 & 0.048 & 53.7 & 48.1 & 22.4 & 25.2 & 4.57 \\
\hline & $\operatorname{SDrI}_{70-50}$ & 2.02 & 0.112 & 0.44 & 3.23 & 0.44 & 0.251 & 0.051 & 53.6 & 50.3 & 21.6 & 23.6 & 4.53 \\
\hline & $\operatorname{DrI}_{100 / 40-50}$ & 2.03 & 0.103 & 0.46 & 4.04 & 0.44 & 0.242 & 0.054 & 71.4 & 62.1 & 24.3 & 27.2 & 5.37 \\
\hline & $\mathrm{SDrI}_{100 / 40-50}$ & 2.04 & 0.114 & 0.47 & 4.33 & 0.49 & 0.282 & 0.080 & 58.3 & 71.2 & 25.1 & 28.5 & 4.87 \\
\hline & $\operatorname{DrI}_{100-100}$ & 2.00 & 0.096 & 0.43 & 3.48 & 0.40 & 0.218 & 0.044 & 60.3 & 59.5 & 23.3 & 26.2 & 5.27 \\
\hline & $\operatorname{SDrI}_{100-100}$ & 2.02 & 0.106 & 0.49 & 3.67 & 0.44 & 0.250 & 0.049 & 63.0 & 61.7 & 24.3 & 28.1 & 5.43 \\
\hline & $\operatorname{DrI}_{70-100}$ & 1.99 & 0.095 & 0.42 & 3.33 & 0.43 & 0.226 & 0.055 & 49.5 & 54.3 & 20.3 & 23.8 & 4.10 \\
\hline & SDrI $_{70-100}$ & 2.08 & 0.114 & 0.50 & 3.31 & 0.45 & 0.259 & 0.061 & 52.7 & 60.3 & 24.5 & 25.0 & 4.50 \\
\hline & $\operatorname{DrI}_{100 / 40-100}$ & 1.99 & 0.091 & 0.41 & 2.80 & 0.41 & 0.215 & 0.058 & 48.7 & 43.6 & 22.3 & 23.8 & 3.87 \\
\hline & $\mathrm{SDrI}_{100 / 40-100}$ & 2.08 & 0.104 & 0.46 & 3.57 & 0.41 & 0.237 & 0.045 & 56.5 & 56.2 & 23.1 & 23.2 & 4.33 \\
\hline \multirow[t]{12}{*}{2008} & $\operatorname{DrI}_{100-50}$ & 2.18 & 0.120 & 0.56 & 4.43 & 0.53 & 0.274 & 0.072 & 55.1 & 53.5 & 48.4 & 35.1 & 7.77 \\
\hline & $\mathrm{SDrI}_{100-50}$ & 2.13 & 0.113 & 0.50 & 4.60 & 0.50 & 0.269 & 0.047 & 49.7 & 71.5 & 56.2 & 37.7 & 9.33 \\
\hline & $\operatorname{DrI}_{70-50}$ & 2.18 & 0.124 & 0.58 & 4.64 & 0.54 & 0.286 & 0.080 & 57.8 & 59.7 & 58.3 & 40.1 & 8.13 \\
\hline & $\mathrm{SDrI}_{70-50}$ & 2.15 & 0.113 & 0.53 & 4.38 & 0.48 & 0.256 & 0.059 & 57.7 & 75.3 & 52.7 & 36.9 & 9.50 \\
\hline & $\operatorname{DrI}_{100 / 40-50}$ & 2.24 & 0.126 & 0.55 & 4.33 & 0.54 & 0.290 & 0.067 & 62.3 & 117.5 & 53.1 & 40.4 & 10.70 \\
\hline & $\mathrm{SDrI}_{100 / 40-50}$ & 2.30 & 0.131 & 0.61 & 4.57 & 0.53 & 0.297 & 0.079 & 76.5 & 52.6 & 47.6 & 33.4 & 7.57 \\
\hline & $\operatorname{DrI}_{100-100}$ & 2.32 & 0.134 & 0.64 & 4.46 & 0.52 & 0.298 & 0.070 & 47.3 & 49.0 & 45.2 & 29.8 & 6.43 \\
\hline & $\mathrm{SDrI}_{100-100}$ & 2.37 & 0.129 & 0.55 & 4.43 & 0.53 & 0.292 & 0.061 & 99.2 & 90.1 & 53.0 & 39.1 & 8.77 \\
\hline & $\operatorname{DrI}_{70-100}$ & 2.23 & 0.128 & 0.53 & 4.41 & 0.58 & 0.283 & 0.071 & 58.0 & 65.7 & 45.1 & 30.7 & 7.80 \\
\hline & $\mathrm{SDrI}_{70-100}$ & 2.24 & 0.127 & 0.56 & 4.66 & 0.54 & 0.286 & 0.071 & 48.3 & 49.7 & 48.3 & 33.6 & 8.70 \\
\hline & $\operatorname{DrI}_{100 / 40-100}$ & 2.23 & 0.130 & 0.61 & 4.56 & 0.56 & 0.299 & 0.085 & 41.7 & 24.1 & 40.6 & 30.9 & 7.17 \\
\hline & $\mathrm{SDrI}_{100 / 40-100}$ & 2.22 & 0.130 & 0.62 & 4.53 & 0.59 & 0.294 & 0.071 & 55.8 & 41.2 & 40.6 & 27.4 & 10.43 \\
\hline \multirow[t]{12}{*}{2009} & DrI $_{100-50}$ & 2.25 & 0.118 & 0.83 & 3.52 & 0.50 & 0.237 & 0.062 & 67.3 & 43.9 & 28.6 & 23.7 & 5.93 \\
\hline & $\mathrm{SDrI}_{100-50}$ & 2.22 & 0.119 & 0.77 & 3.84 & 0.49 & 0.240 & 0.061 & 62.0 & 44.2 & 29.8 & 26.9 & 5.27 \\
\hline & $\operatorname{DrI}_{70-50}$ & 2.23 & 0.106 & 0.73 & 3.36 & 0.47 & 0.211 & 0.059 & 52.3 & 48.3 & 27.6 & 24.9 & 5.50 \\
\hline & $\mathrm{SDrI}_{70-50}$ & 2.25 & 0.107 & 0.74 & 3.36 & 0.45 & 0.214 & 0.050 & 52.9 & 38.9 & 27.2 & 24.5 & 5.87 \\
\hline & $\operatorname{DrI}_{100 / 40-50}$ & 2.27 & 0.112 & 0.81 & 3.59 & 0.52 & 0.228 & 0.060 & 71.4 & 44.3 & 28.5 & 25.8 & 5.33 \\
\hline & $\mathrm{SDrI}_{100 /}$ & 2.25 & 0.108 & 0.71 & 3.57 & 0.48 & 0.222 & 0.058 & 53.0 & 42.6 & 26.4 & 22.5 & 5.13 \\
\hline & $\operatorname{DrI}_{100-100}$ & 2.25 & 0.116 & 0.75 & 3.58 & 0.50 & 0.244 & 0.056 & 58.4 & 37.0 & 29.6 & 26.2 & 5.43 \\
\hline & $\operatorname{SDrI}_{100-100}$ & 2.28 & 0.109 & 0.70 & 3.54 & 0.46 & 0.237 & 0.053 & 69.1 & 47.4 & 32.8 & 32.2 & 6.10 \\
\hline & $\operatorname{DrI}_{70-100}$ & 2.27 & 0.122 & 0.85 & 3.46 & 0.53 & 0.242 & 0.070 & 65.2 & 45.4 & 29.3 & 25.1 & 5.80 \\
\hline & $\mathrm{SDrI}_{70-100}$ & 2.22 & 0.115 & 0.86 & 3.53 & 0.48 & 0.232 & 0.060 & 81.2 & 49.1 & 31.1 & 30.4 & 5.97 \\
\hline & $\operatorname{DrI}_{100 / 40-100}$ & 2.20 & 0.112 & 0.86 & 3.31 & 0.48 & 0.211 & 0.067 & 59.1 & 40.3 & 30.1 & 29.1 & 6.03 \\
\hline & $\mathrm{SDrI}_{100 / 40-100}$ & 2.27 & 0.114 & 0.75 & 3.49 & 0.48 & 0.235 & 0.058 & 60.2 & 41.8 & 30.6 & 27.1 & 6.77 \\
\hline \multirow[t]{12}{*}{2010} & $\mathrm{DrI}_{100-50}$ & 2.44 & 0.105 & 0.83 & 3.28 & 0.43 & 0.222 & 0.056 & 84.5 & 58.0 & 33.37 & 25.3 & 5.43 \\
\hline & $\mathrm{SDrI}_{100-50}$ & 2.42 & 0.102 & 0.86 & 3.30 & 0.43 & 0.224 & 0.054 & 86.0 & 55.6 & 33.5 & 24.8 & 5.03 \\
\hline & DrI $70-50$ & 2.40 & 0.102 & 0.96 & 3.39 & 0.45 & 0.214 & 0.052 & 58.7 & 58.9 & 32.7 & 30.4 & 5.63 \\
\hline & SDrI $70-50$ & 2.41 & 0.108 & 1.04 & 3.43 & 0.45 & 0.234 & 0.055 & 67.4 & 53.5 & 31.8 & 27.5 & 5.33 \\
\hline & $\operatorname{DrI}_{100 / 40-50}$ & 2.43 & 0.101 & 0.97 & 3.34 & 0.44 & 0.221 & 0.057 & 82.9 & 57.9 & 31.0 & 24.4 & 4.57 \\
\hline & $\mathrm{SDrI}_{100 / 40-50}$ & 2.44 & 0.108 & 0.82 & 3.49 & 0.46 & 0.250 & 0.061 & 74.2 & 69.4 & 33.1 & 25.9 & 5.40 \\
\hline & $\operatorname{DrI}_{100-100}$ & 2.40 & 0.112 & 1.08 & 3.64 & 0.47 & 0.236 & 0.062 & 72.3 & 73.9 & 33.8 & 32.5 & 5.60 \\
\hline & SDrI $_{100-100}$ & 2.43 & 0.105 & 0.83 & 3.37 & 0.45 & 0.229 & 0.048 & 69.4 & 67.9 & 32.0 & 29.7 & 5.80 \\
\hline & $\operatorname{DrI}_{70-100}$ & 2.39 & 0.092 & 0.87 & 3.14 & 0.43 & 0.201 & 0.058 & 65.0 & 54.2 & 31.4 & 28.0 & 4.67 \\
\hline & $\mathrm{SDrI}_{70-100}$ & 2.40 & 0.108 & 1.04 & 3.49 & 0.47 & 0.238 & 0.063 & 73.1 & 59.2 & 31.3 & 19.7 & 5.53 \\
\hline & $\operatorname{DrI}_{100 / 40-100}$ & 2.42 & 0.096 & 0.91 & 3.22 & 0.45 & 0.208 & 0.059 & 66.9 & 58.4 & 32.9 & 24.5 & 5.40 \\
\hline & $\mathrm{SDrI}_{100 / 40-100}$ & 2.44 & 0.102 & 0.96 & 3.28 & 0.45 & 0.224 & 0.057 & 54.5 & 56.9 & 31.6 & 24.7 & 5.43 \\
\hline
\end{tabular}




\begin{tabular}{rrllllllllllll}
\hline ANOVA $^{1}$ & IS $^{2}$ & NS & NS & NS & NS & NS & NS & NS & NS & NS & NS & NS & NS \\
& RDI $^{3}$ & NS & NS & NS & NS & NS & NS & NS & NS & NS & NS & NS & NS \\
UEP $^{4}$ & NS & NS & NS & NS & NS & NS & NS & NS & NS & NS & NS & NS \\
Year & $* * *$ & $* * *$ & $* * *$ & $* * *$ & $* * *$ & NS & $* * *$ & $* *$ & $* * *$ & $* * *$ & $* * *$ & $* * *$ \\
IS $\times$ RDI & NS & NS & NS & NS & NS & NS & NS & NS & NS & NS & NS & NS \\
IS $\times$ UEP & NS & NS & NS & NS & NS & NS & NS & NS & NS & NS & NS & NS \\
IS $\times$ Year & NS & NS & NS & NS & NS & NS & NS & NS & NS & NS & NS & NS \\
RDI x UEP & NS & NS & NS & NS & NS & NS & NS & NS & NS & NS & NS & NS \\
RDI x Year & NS & NS & NS & NS & NS & NS & NS & NS & NS & NS & NS & NS \\
UEP x Year & NS & NS & NS & NS & NS & NS & NS & NS & NS & NS & NS & NS \\
\hline
\end{tabular}

Table 4. Effect of irrigation strategies on macronutrient concentration (\% dry weight) and micronutrient (ppm) concentration. ${ }^{1}$ ANOVA: Significant effects of different irrigation strategies are given at $\mathrm{P}>0,05$ (NS, not significant ), $\mathrm{P} \leq 0,05\left(^{*}\right), \mathrm{P} \leq 0,01\left(^{* *}\right), \mathrm{P} \leq 0,001\left(^{* * *}\right)$. 2IS: irrigation system (SDrI and DrI); ${ }^{3} \mathrm{RDI}$ : Regulated deficit irrigation (Control, 70 and 100-40 \% ETc). ${ }^{4} \mathrm{UEP}:$ coefficient use in effective precipitation (50 and $100 \%$ CA).

improve irrigation and fertilizer use efficiency because water and nutrients are applied directly to the root zone (Camp, 1998). Boss (1985) also obtained less WP in drip irrigated trees (microjets) than trees irrigated by subsurface drip. However, Bryla et al. (2003) did not observe significant differences in this variable between peach trees irrigated by surface and subsurface drip.

Concerning the effect of deficit irrigation, water use significantly increased by increasing water stress. García-Tejero et al. (2011) affirmed that WP was strongly influenced by the irrigation strategy employed at different phenological stages, rather than the amount of water in orange trees subjected to different deficit irrigation regimes. In this sense, the best results were registered when stress was applied at fruit maturity. However, the most restrictive treatment during fruit growth had a descending WP, registering values below even the fully irrigated treatment. Treatments in which water stress was applied at flowering and maturity showed similar WP values. Clearly, WP depends not only on the total water applied but also on when it is applied. Dissimilar results were found by Ibrahim and Abd El-Samad (2009) for pomegranate trees irrigated at $70 \%, 50 \%$ and $30 \%$ of available soil water. WP diminishing in trees with high deficit irrigation regimes (46-52 \% and 2-6\% of tree water needs).

The factor used to calculate the volume of rainwater available to the root system also affected the WP variable. Thus, efficiency values were higher in trees that theoretically used $100 \%$ of CA than in those that used $50 \%$. As indicated, there is no information available on the different UEP factor effects on water irrigation savings.

\section{Effect of irrigation management on fruit quality parameters}

With regard to fruit quality (Table 7), the studied factors and their interactions did not significantly affect peel thickness, or the percentage of pulp or juice. Only UEP significantly affected juice percentage with higher values in $50 \%$ CA irrigated trees. This result could be due to the high volume of water applied in these plants. In other studies on grapefruit (Cruse et al., 1982), orange (Castel and Buj, 1990), Satsuma mandarin (Salustiano, Rabe and Peng, 1998) and Nules mandarin (Velez et al., 2007) significant differences due to differential irrigation doses were not found for these parameters either. 


\begin{tabular}{|c|c|c|c|c|c|}
\hline Year & Treatments & Yield $\left(\mathrm{kg}\right.$ tree $\left.^{-1}\right)$ & Fruit weight (g) & $\mathrm{N}^{o}$ fruit tree -1 & $\mathrm{WP}\left(\mathrm{kg} \mathrm{m}^{-3}\right)$ \\
\hline \multirow[t]{12}{*}{2007} & $\operatorname{DrI}_{100-50}$ & 62.5 & 107.1 & 597 & 6.45 \\
\hline & $\mathrm{SDrI}_{100-50}$ & 66.6 & 110.8 & 610 & 6.90 \\
\hline & DrI70-50 & 68.3 & 107.6 & 651 & 6.95 \\
\hline & $\mathrm{SDrI}_{70-50}$ & 74.0 & 110.2 & 679 & 7.55 \\
\hline & $\operatorname{DrI}_{100 / 40-50}$ & 72.3 & 106.1 & 700 & 9.10 \\
\hline & $\mathrm{SDrI}_{100 / 40-50}$ & 73.0 & 112.3 & 662 & 9.20 \\
\hline & $\operatorname{DrI}_{100-100}$ & 69.4 & 109.4 & 647 & 8.50 \\
\hline & $\mathrm{SDrI}_{100-100}$ & 76.3 & 110.7 & 701 & 9.35 \\
\hline & DrI70-100 & 59.3 & 99.7 & 596 & 7.50 \\
\hline & $\mathrm{SDrI}_{70-100}$ & 73.8 & 105.1 & 707 & 9.30 \\
\hline & $\operatorname{DrI}_{100 / 40-100}$ & 66.0 & 107.3 & 616 & 8.10 \\
\hline & $\mathrm{SDrI}_{100 / 40-100}$ & 74.2 & 108.8 & 686 & 9.15 \\
\hline \multirow[t]{12}{*}{2008} & $\operatorname{DrI}_{100-50}$ & 26.0 & 103.2 & 252 & 4.09 \\
\hline & $\mathrm{SDrI}_{100-50}$ & 38.7 & 94.1 & 411 & 6.44 \\
\hline & $\operatorname{DrI}_{70-50}$ & 39.7 & 88.5 & 450 & 7.13 \\
\hline & $\mathrm{SDrI}_{70-50}$ & 38.2 & 97.3 & 392 & 6.87 \\
\hline & $\operatorname{DrI}_{100 / 40-50}$ & 28.6 & 92.6 & 306 & 5.10 \\
\hline & $\mathrm{SDrI}_{100 / 40-50}$ & 37.6 & 89.6 & 426 & 6.72 \\
\hline & $\mathrm{DrI}_{100-100}$ & 39.1 & 107.1 & 365 & 7.18 \\
\hline & SDrI $_{100-100}$ & 41.1 & 100.7 & 418 & 7.53 \\
\hline & $\operatorname{DrI}_{70-100}$ & 41.8 & 94.9 & 422 & 9.24 \\
\hline & $\mathrm{SDrI}_{70-100}$ & 45.6 & 102.4 & 445 & 10.10 \\
\hline & DrI $_{100 / 40-100}$ & 35.2 & 95.3 & 364 & 7.72 \\
\hline & $\mathrm{SDrI}_{100 / 40-100}$ & 47.4 & 97.0 & 486 & 10.39 \\
\hline \multirow[t]{12}{*}{2009} & DrI $_{100-50}$ & 39.7 & 112.6 & 353 & 4.63 \\
\hline & $\mathrm{SDrI}_{100-50}$ & 48.4 & 110.4 & 442 & 5.64 \\
\hline & $\operatorname{DrI}_{70-50}$ & 48.6 & 99.2 & 484 & 6.78 \\
\hline & SDrI $_{70-50}$ & 50.0 & 94.7 & 528 & 6.98 \\
\hline & $\operatorname{DrI}_{100 / 40-50}$ & 33.0 & 95.1 & 350 & 4.63 \\
\hline & $\mathrm{SDrI}_{100 / 40-50}$ & 42.4 & 100.4 & 422 & 5.95 \\
\hline & $\operatorname{DrI}_{100-100}$ & 44.5 & 111.0 & 402 & 4.94 \\
\hline & $\mathrm{SDrI}_{100-100}$ & 53.0 & 103.7 & 521 & 5.89 \\
\hline & $\operatorname{DrI}_{70-100}$ & 35.9 & 107.4 & 334 & 4.84 \\
\hline & SDrI $_{70-100}$ & 47.9 & 104.9 & 482 & 6.46 \\
\hline & $\operatorname{DrI}_{100 / 40-100}$ & 30.0 & 101.5 & 296 & 4.05 \\
\hline & $\mathrm{SDrI}_{100 / 40-100}$ & 46.3 & 105.7 & 439 & 6.26 \\
\hline \multirow[t]{12}{*}{2010} & $\operatorname{DrI}_{100-50}$ & 31.1 & 96.0 & 324 & 3.8 \\
\hline & $\mathrm{SDrI}_{100-50}$ & 32.8 & 95.9 & 343 & 4.0 \\
\hline & DrI70-50 & 31.9 & 92.0 & 347 & 4.9 \\
\hline & $\mathrm{SDrI}_{70-50}$ & 28.8 & 89.6 & 326 & 4.5 \\
\hline & $\operatorname{DrI}_{100 / 40-50}$ & 28.8 & 693.5 & 314 & 4.5 \\
\hline & $\mathrm{SDrI}_{100 / 40-50}$ & 26.1 & 91.8 & 289 & 4.1 \\
\hline & $\operatorname{DrI}_{100-100}$ & 30.9 & 102.9 & 300 & 4.8 \\
\hline & $\mathrm{SDrI}_{100-100}$ & 35.5 & 95.9 & 372 & 5.5 \\
\hline & DrI $_{70-100}$ & 21.8 & 103.1 & 210 & 4.8 \\
\hline & $\mathrm{SDrI}_{70-100}$ & 33.4 & 100.2 & 335 & 7.4 \\
\hline & $\operatorname{DrI}_{100 / 40-100}$ & 21.8 & 93.9 & 234 & 4.8 \\
\hline & $\mathrm{SDrI}_{100 / 40-100}$ & 34.3 & 94.2 & 361 & 7.6 \\
\hline
\end{tabular}




\begin{tabular}{rrrccc}
\hline ANOVA $^{1}$ & IS $^{2}$ & $* * *$ & NS & $* * *$ & $* * *$ \\
RDI $^{3}$ & NS & $*$ & NS & $*$ \\
UEP $^{4}$ & NS & $*$ & NS & $* * *$ \\
Year & $* * *$ & $* * *$ & NS & NS \\
IS $x$ RDI & NS & NS & NS & NS \\
IS x UEP & NS & NS & NS & NS \\
IS x Year & NS & NS & NS & NS \\
RDI x UEP & NS & NS & NS & NS \\
RDI x Year & NS & NS & NS & NS \\
UEP x Year & NS & NS & S
\end{tabular}

Table 5. Effect of irrigation strategies on yield and fruit parameters and water use efficiency. ${ }_{1}^{1}$ ANOVA: Significant effects of different irrigation strategies are given at $\mathrm{P}>0,05$ (NS, not significant ), $\mathrm{P} \leq 0,05\left({ }^{*}\right), \mathrm{P} \leq 0,01\left({ }^{* *}\right), \mathrm{P} \leq 0,001\left({ }^{* * *}\right)$. ${ }^{2} \mathrm{IS}$ : irrigation system (SDrI and DrI); ${ }^{3} \mathrm{RDI}$ : Regulated deficit irrigation (Control, 70 and 100-40 \% ETc). ${ }^{4}$ UEP: coefficient use in effective precipitation (50 and $100 \% \mathrm{CA}$ ).

As for the other quality parameters analysed, both IS and RDI and their interaction significantly affected total acidity (TA), total soluble solids (TSS) and maturity index (IM). In drip irrigated trees, control trees showed higher TA and IM than that recorded for the juice of fruits from deficit irrigated plants (70 or alternate irrigation events $40-100 \%$ ETc). However, under subsurface drip irrigation an opposite trend was observed. Regarding TSS, higher values were recorded in drip irrigated trees and under water stress conditions. Similarly to what occurs in SDrI, Ginestar and Castel (1996) only detected an increase (albeit insignificant) in acidity on decreasing water doses in drip irrigated trees of Nules clementine. Other researchers (Cruse et al., 1982; Koo and Smajstrla, 1985, Castel and Buj, 1990; Eliades, 1994, Peng and Rabe, 1998) described a similar pattern to that described in this assay. Velez et al. (2007) observed that fruit quality parameters were slightly altered by the deficit irrigation applied. Thus, fruit from the deficit irrigated trees was more acidic and was not sweeter than that from the control trees in the first year of the assay, but fruit from water stress trees had significantly higher Brix and similar acidity in the second year. On the other hand, in both years, the MI was not significantly altered by the water restrictions applied. Pérez-Sarmiento et al. (2010) also found that TSS values were increased significantly by RDI treatment, whereas TA was equal in control and deficit treatments, and therefore the TSS/TA ratio increased significantly in the RDI treatment. Thus, fruits from RDI treatment can be considered of high quality since TSS increased without affecting acidity (Scandella et al., 1997).

RDI has been used successfully, maintaining yield and fruit quality, including higher values of total soluble solids, tritratable acidity in many fruit species (Ebel et al., 1995; López et al., 2008), citrus species (Sánchez-Blanco et al., 1989; Castel and Buj, 1990; Domingo et al., 1996; González-Altozano and Castel, 1999; Goldhamer and Salinas, 2000), apricot trees (RuizSanchez et al., 2000), nut species (Romero et al., 2004), wine grape vines (Bravdo and Naor, 1996; McCarthy et al., 2002) and olives (Moriana et al., 2003).

The analysis of fruit peel colour (CI) showed that only IS affected this variable, with greener fruit corresponding to the DrI treatments than those obtained for SDrI. An opposite pattern was obtained in apricot fruit indices (Pérez-Sarmiento et al., 2010). Fruits from RDI treated trees showed higher CI values. The increase in this parameter in apricot fruits from RDI plants can be associated to a reduction in carotenoid accumulation, attributed to oxidation 


\begin{tabular}{|c|c|c|c|c|c|c|c|}
\hline Year & Treatments & Calliper & $>78 \mathrm{~mm}$ & $78-67$ & $67-58$ & $58-50$ & $<50$ \\
\hline \multirow[t]{12}{*}{2007} & $\mathrm{DrI}_{100-50}$ & 62.5 & 0.3 & 14.41 & 43.9 & 36.7 & 4,7 \\
\hline & $\mathrm{SDrI}_{100-50}$ & 66.6 & 0.0 & 9.5 & 41.7 & 44.3 & 4,5 \\
\hline & $\operatorname{DrI}_{70-50}$ & 68.3 & 0.0 & 3.8 & 40.3 & 45.3 & 10,6 \\
\hline & $\mathrm{SDrI}_{70-50}$ & 74.0 & 0.0 & 5.1 & 47.3 & 41.6 & 6,0 \\
\hline & $\operatorname{DrI}_{100 / 40-50}$ & 72.3 & 0.0 & 11.7 & 46.7 & 38.0 & 3,6 \\
\hline & $\mathrm{SDrI}_{100 / 40-50}$ & 73.0 & 0.3 & 8.7 & 50.0 & 35.5 & 5,5 \\
\hline & $\operatorname{DrI}_{100-100}$ & 69.4 & 0.3 & 11.4 & 50.5 & 35.3 & 2,5 \\
\hline & $\mathrm{SDrI}_{100-100}$ & 76.3 & 0.0 & 9.7 & 55.5 & 29.6 & 5,2 \\
\hline & $\operatorname{DrI}_{70-100}$ & 59.3 & 0.0 & 9.0 & 49.8 & 35.1 & 6,1 \\
\hline & $\operatorname{SDrI}_{70-100}$ & 73.8 & 0.6 & 12.0 & 52.5 & 30.2 & 4,7 \\
\hline & $\operatorname{DrI}_{100 / 40-100}$ & 66.0 & 0.0 & 11.7 & 53.0 & 31.7 & 3,6 \\
\hline & $\mathrm{SDrI}_{100 / 40-100}$ & 74.2 & 0.6 & 7.2 & 53.4 & 35.9 & 2,9 \\
\hline \multirow[t]{12}{*}{2008} & DrI $_{100-50}$ & 61.9 & 0.0 & 18.9 & 64.6 & 16.1 & 0,4 \\
\hline & $\mathrm{SDrI}_{100-50}$ & 61.8 & 0.5 & 15.6 & 66.5 & 17.1 & 0,3 \\
\hline & $\operatorname{DrI}_{70-50}$ & 59.7 & 0.0 & 9.0 & 63.6 & 26.1 & 1,3 \\
\hline & $\mathrm{SDrI}_{70-50}$ & 60.9 & 0.0 & 15.3 & 66.7 & 17.1 & 0,9 \\
\hline & $\operatorname{DrI}_{100 / 40-50}$ & 60.7 & 0.0 & 14.2 & 61.7 & 23.8 & 0,3 \\
\hline & $\mathrm{SDrI}_{100 / 40-50}$ & 60.7 & 0.0 & 22.1 & 56.2 & 21.4 & 0,3 \\
\hline & $\operatorname{DrI}_{100-100}$ & 62.7 & 0.0 & 25.2 & 61.1 & 13.4 & 0,3 \\
\hline & $\mathrm{SDrI}_{100-100}$ & 62.1 & 0.9 & 23.6 & 56.6 & 15.2 & 3,7 \\
\hline & DrI $70-100$ & 60.9 & 0.5 & 15.6 & 62.7 & 20.3 & 0,9 \\
\hline & $\mathrm{SDrI}_{70-100}$ & 62.3 & 0.0 & 24.0 & 62.0 & 13.0 & 1,0 \\
\hline & $\operatorname{DrI}_{100 / 40-100}$ & 60.4 & 0.0 & 13.7 & 60.3 & 25.2 & 0,8 \\
\hline & $\mathrm{SDrI}_{100 / 40-100}$ & 61.2 & 0.0 & 14.4 & 65.4 & 19.9 & 0,3 \\
\hline \multirow[t]{12}{*}{2009} & $\operatorname{DrI}_{100-50}$ & 59.8 & 0.6 & 20.6 & 47.2 & 29.2 & 2,4 \\
\hline & $\mathrm{SDrI}_{100-50}$ & 58.8 & 0.0 & 14.1 & 46.2 & 36.9 & 2,8 \\
\hline & DrI70-50 & 57.1 & 0.0 & 6.4 & 47.1 & 39.7 & 6,8 \\
\hline & $\mathrm{SDrI}_{70-50}$ & 58.3 & 0.0 & 7.8 & 54.1 & 34.5 & 3,6 \\
\hline & $\operatorname{DrI}_{100 / 40-50}$ & 59.4 & 0.0 & 18.2 & 50.0 & 29.6 & 2,2 \\
\hline & $\mathrm{SDrI}_{100 / 40-50}$ & 59.4 & 0.6 & 12.8 & 54.5 & 28.7 & 3,4 \\
\hline & DrI $_{100-100}$ & 60.0 & 0.0 & 17.1 & 50.0 & 27.4 & 5,5 \\
\hline & $\mathrm{SDrI}_{100-100}$ & 59.8 & 0.0 & 14.8 & 59.4 & 23.0 & 2,8 \\
\hline & $\operatorname{DrI}_{70-100}$ & 59.2 & 0.0 & 12.2 & 54.9 & 29.0 & 3,9 \\
\hline & $\operatorname{SDrI}_{70-100}$ & 60.5 & 1.1 & 17.0 & 55.6 & 24.2 & 2,1 \\
\hline & $\operatorname{DrI}_{100 / 40-100}$ & 60.2 & 0.0 & 17.2 & 56.7 & 24.1 & 2,0 \\
\hline & $\mathrm{SDrI}_{100 / 40-100}$ & 59.6 & 1.1 & 10.9 & 57.4 & 28.7 & 1,9 \\
\hline \multirow[t]{12}{*}{2010} & DrI $_{100-50}$ & 59.2 & 0.0 & 8.1 & 47.1 & 39.3 & 5,5 \\
\hline & $\mathrm{SDrI}_{100-50}$ & 59.0 & 0.6 & 6.3 & 47.96 & 43.9 & 1,2 \\
\hline & $\operatorname{DrI}_{70-50}$ & 58.3 & 0.0 & 3.8 & 46.8 & 46.2 & 3,2 \\
\hline & SDrI $_{70-50}$ & 59.7 & 0.3 & 10.8 & 46.7 & 40.8 & 1,4 \\
\hline & $\operatorname{DrI}_{100 / 40-50}$ & 58.9 & 0.0 & 6.8 & 49.5 & 40.1 & 3,6 \\
\hline & $\mathrm{SDrI}_{100 / 40-50}$ & 58.4 & 0.0 & 4.2 & 44.1 & 49.8 & 1,9 \\
\hline & DrI $I_{100-100}$ & 60.4 & 0.0 & 10.5 & 57.0 & 31.4 & 1,1 \\
\hline & $\mathrm{SDrI}_{100-100}$ & 59.9 & 0.0 & 9.0 & 51.4 & 37.6 & 2,0 \\
\hline & DrI70-100 & 60.1 & 0.0 & 9.6 & 54.1 & 33.6 & 2,7 \\
\hline & $\operatorname{SDrI}_{70-100}$ & 59.9 & 0.0 & 7.4 & 54.4 & 36.6 & 1,6 \\
\hline & $\operatorname{DrI}_{100 / 40-100}$ & 59.7 & 0.0 & 11.3 & 47.8 & 37.4 & 3,5 \\
\hline & $\mathrm{SDrI}_{100 / 40-100}$ & 59.2 & 0.3 & 8.6 & 49.3 & 38.5 & 3,3 \\
\hline
\end{tabular}




\begin{tabular}{rrrcclll}
\hline ANOVA $^{1}$ & IS $^{2}$ & NS & $*$ & NS & NS & NS & NS \\
& RDI $^{3}$ & $*$ & NS & $* *$ & NS & NS & NS \\
UEP $^{4}$ & $* *$ & NS & $*$ & $* * *$ & $* * *$ & NS \\
Year & $* * *$ & NS & $* * *$ & $* * *$ & $* * *$ & $* * *$ \\
IS x RDI & NS & NS & NS & NS & NS & NS \\
IS $\times$ UEP & NS & NS & NS & NS & NS & NS \\
IS x Year & NS & NS & NS & NS & NS & NS \\
RDRI x UEP & NS & NS & NS & NS & NS & NS \\
RDRI x Year & NS & NS & NS & NS & NS & NS \\
UEP x Year & NS & NS & NS & NS & NS & NS \\
\hline
\end{tabular}

Table 6. Effect of irrigation strategies on fruit calliper and percentage of fruit in each commercial calliper. ${ }^{1}$ ANOVA: Significant effects of different irrigation strategies are given at $\mathrm{P}>0,05$ (NS, not significant ), $\mathrm{P} \leq 0,05\left({ }^{*}\right), \mathrm{P} \leq 0,01\left({ }^{* *}\right), \mathrm{P} \leq 0,001\left({ }^{* * *}\right) .{ }^{2} \mathrm{IS}$ : irrigation system (SDrI and DrI); ${ }^{3 R D I}$ : Regulated deficit irrigation (Control, 70 and 100-40\% ETc). ${ }^{4}$ UEP: coefficient use in effective precipitation (50 and $100 \%$ CA).

\begin{tabular}{|c|c|c|c|c|c|c|c|c|}
\hline Year & Treatments & $\begin{array}{c}\text { Peel } \\
\text { thickness }\end{array}$ & $\%$ Peel & \% Juice & $\mathrm{TA}^{5}\left({ }^{\circ}\right.$ Brix $)$ & TSS $^{6}$ & $\mathrm{IM}^{7}$ & $\mathrm{CI}^{8}$ \\
\hline \multirow{12}{*}{2007} & DrI $_{100-50}$ & 2.95 & 52.4 & 47.6 & 0.88 & 13.2 & 15,0 & 8.8 \\
\hline & $\mathrm{SDrI}_{100-50}$ & 2.85 & 51.7 & 48.3 & 0.89 & 12.9 & 14,5 & 8.5 \\
\hline & $\operatorname{DrI}_{70-50}$ & 3.85 & 50.8 & 49.2 & 0.94 & 13.1 & 13,9 & 8.0 \\
\hline & $\mathrm{SDrI}_{70-50}$ & 3.40 & 50.9 & 49.1 & 0.91 & 13.1 & 14,4 & 8.3 \\
\hline & $\operatorname{DrI}_{100 / 40-50}$ & 3.00 & 51.6 & 48.4 & 0.89 & 13.2 & 14,8 & 8.3 \\
\hline & $\mathrm{SDrI}_{100 / 40-50}$ & 2.85 & 50.4 & 49.6 & 0.89 & 12.9 & 14,5 & 9.4 \\
\hline & $\operatorname{DrI}_{100-100}$ & 2.95 & 52.4 & 47.6 & 0.97 & 13.3 & 13,7 & 9.1 \\
\hline & SDrI $100-100$ & 2.90 & 51.4 & 48.6 & 0.92 & 13.2 & 14,3 & 8.5 \\
\hline & $\operatorname{DrI}_{70-100}$ & 2.75 & 50.7 & 49.3 & 1.04 & 14.1 & 13,6 & 9.0 \\
\hline & $\mathrm{SDrI}_{70-100}$ & 2.80 & 50.8 & 49.2 & 0.91 & 13.3 & 14,6 & 9.8 \\
\hline & $\operatorname{DrI}_{100 / 40-100}$ & 2.90 & 52.0 & 48 & 0.99 & 13.8 & 13,9 & 8.9 \\
\hline & $\mathrm{SDrI}_{100 / 40-100}$ & 2.85 & 51.4 & 48.6 & 0.91 & 13.5 & 14,8 & 9.4 \\
\hline \multirow[t]{12}{*}{2008} & $\operatorname{DrI}_{100-50}$ & 3.50 & 49.1 & 50.9 & 0.90 & 13.6 & 15,1 & 9.6 \\
\hline & $\mathrm{SDrI}_{100-50}$ & 3.37 & 49.1 & 50.9 & 0.97 & 13.2 & 13,6 & 9.3 \\
\hline & $\operatorname{DrI}_{70-50}$ & 3.37 & 48.8 & 51.2 & 0.90 & 14.0 & 15,6 & 9.6 \\
\hline & $\mathrm{SDrI}_{70-50}$ & 3.47 & 50.9 & 49.1 & 0.87 & 13.4 & 15,4 & 9.4 \\
\hline & $\operatorname{DrI}_{100 / 40-50}$ & 3.57 & 51.5 & 48.5 & 0.93 & 14.1 & 15,2 & 8.5 \\
\hline & SDrI $_{100 / 40-50}$ & 3.43 & 48.7 & 51.3 & 0.93 & 13.9 & 14,9 & 9.3 \\
\hline & $\operatorname{DrI}_{100-100}$ & 3.40 & 49.4 & 50.6 & 0.87 & 12.6 & 14,5 & 8.3 \\
\hline & SDrI $_{100-100}$ & 3.40 & 49.7 & 50.3 & 0.87 & 12.7 & 14,6 & 9.1 \\
\hline & DrI $70-100$ & 3.43 & 49.5 & 50.5 & 0.93 & 13.1 & 14,1 & 9.2 \\
\hline & $\mathrm{SDrI}_{70-100}$ & 3.53 & 50.0 & 50 & 0.90 & 13.2 & 14,7 & 11.0 \\
\hline & $\operatorname{DrI}_{100 / 40-100}$ & 3.43 & 49.7 & 50.3 & 1.00 & 13.7 & 13,7 & 9.8 \\
\hline & $\mathrm{SDrI}_{100 / 40-100}$ & 3.37 & 48.6 & 51.4 & 0.80 & 13.2 & 16,5 & 9.2 \\
\hline \multirow[t]{8}{*}{2009} & $\operatorname{DrI}_{100-50}$ & 3.29 & 51.9 & 48.1 & 1.02 & 12.7 & 12,5 & 7.8 \\
\hline & $\mathrm{SDrI}_{100-50}$ & 3.15 & 51.7 & 48.3 & 1.00 & 124 & 12,4 & 10.4 \\
\hline & DrI $70-50$ & 3.21 & 50.9 & 49.1 & 1.02 & 13.1 & 12,8 & 7.9 \\
\hline & $\mathrm{SDrI}_{70-50}$ & 3.04 & 50.0 & 50 & 1.04 & 12.6 & 12,1 & 8.0 \\
\hline & $\operatorname{DrI}_{100 / 40-50}$ & 3.04 & 51.2 & 48.8 & 1.15 & 13.0 & 11,3 & 6.8 \\
\hline & $\mathrm{SDrI}_{100 / 40-50}$ & 3.24 & 51.6 & 48.4 & 1.09 & 12.8 & 11,7 & 6.4 \\
\hline & $\operatorname{DrI}_{100-100}$ & 3.20 & 53.2 & 46.8 & 1.04 & 12.7 & 12,2 & 7.0 \\
\hline & SDrI $_{100-100}$ & 2.98 & 51.4 & 48.6 & 1.11 & 12.7 & 11,4 & 6.8 \\
\hline
\end{tabular}




\begin{tabular}{|c|c|c|c|c|c|c|c|c|}
\hline & $\operatorname{DrI}_{70-100}$ & 3.27 & 53.0 & 47 & 1.10 & 12.6 & 11,5 & 7.8 \\
\hline & $\mathrm{SDrI}_{70-100}$ & 3.18 & 51.8 & 48.2 & 1.02 & 12.6 & 12,4 & 9.0 \\
\hline & $\operatorname{DrI}_{100 / 40-100}$ & 3.12 & 52.9 & 47.1 & 1.13 & 12.6 & 11,2 & 7.0 \\
\hline & $\mathrm{SDrI}_{100 / 40-100}$ & 3.01 & 52.0 & 48 & 0.96 & 12.9 & 13,4 & 9.5 \\
\hline 2010 & $\operatorname{DrI}_{100-50}$ & 2.84 & 49.6 & 50.4 & 1.16 & 12.9 & 11,1 & \\
\hline & $\mathrm{SDrI}_{100-50}$ & 2.94 & 52.0 & 48 & 1.16 & 13.0 & 11,2 & \\
\hline & DrI $_{70-50}$ & 2.93 & 51.9 & 48.1 & 1.33 & 14.2 & 10,7 & \\
\hline & $\mathrm{SDrI}_{70-50}$ & 2.75 & 50.9 & 49.1 & 1.16 & 13.0 & 11,2 & \\
\hline & $\operatorname{DrI}_{100 / 40-50}$ & 3.00 & 51.0 & 49 & 1.33 & 14.0 & 10,5 & \\
\hline & $\mathrm{SDrI}_{100 / 40-50}$ & 2.93 & 51.3 & 48.7 & 1.15 & 13.0 & 11,3 & \\
\hline & $\operatorname{DrI}_{100-100}$ & 2.93 & 48.3 & 51.7 & 1.19 & 13.0 & 10,9 & \\
\hline & SDrI $100-100$ & 2.76 & 52.3 & 47.7 & 1.18 & 13.1 & 11,1 & \\
\hline & DrI $_{70-100}$ & 3.12 & 52.1 & 47.9 & 1.28 & 13.6 & 10,6 & \\
\hline & $\mathrm{SDrI}_{70-100}$ & 3.07 & 54.8 & 45.2 & 1.20 & 13.5 & 11,3 & \\
\hline & $\operatorname{DrI}_{100 / 40-100}$ & 3.18 & 53.1 & 46.9 & 1.29 & 14.0 & 10,9 & \\
\hline & SDrI $_{100 / 40-100}$ & 2.94 & 53.7 & 46.3 & 1.23 & 13.5 & 11,0 & \\
\hline ANOVA $^{1}$ & IS $^{2}$ & NS & NS & NS & *** & $* * *$ & * & * \\
\hline & $\mathrm{RDI}^{3}$ & NS & NS & NS & NS & $* * *$ & NS & NS \\
\hline & $\mathrm{UEP}^{4}$ & NS & NS & * & NS & NS & NS & NS \\
\hline & Year & $* * *$ & $* * *$ & $* * *$ & $* * *$ & $* * *$ & $* * *$ & $* * *$ \\
\hline & IS $x$ RDI & NS & NS & NS & ** & NS & ** & NS \\
\hline & IS $x$ UEP & NS & NS & NS & NS & NS & NS & NS \\
\hline & IS $x$ Year & NS & NS & NS & NS & NS & NS & NS \\
\hline & RDRI $\times$ UEP & NS & NS & NS & NS & NS & NS & NS \\
\hline & RDRI $\times$ Year & NS & NS & NS & NS & NS & NS & NS \\
\hline & UEP x Year & NS & NS & NS & NS & NS & NS & NS \\
\hline
\end{tabular}

Table 7. Effect of irrigation strategies on fruit quality parameters. ${ }^{1}$ ANOVA: Significant effects of different irrigation strategies are given at $\mathrm{P}>0,05$ (NS, not significant ), $\mathrm{P} \leq 0,05\left(^{*}\right), \mathrm{P} \leq 0,01$ $\left({ }^{* *}\right), \mathrm{P} \leq 0,001\left({ }^{* *}\right) .{ }^{2} \mathrm{IS}$ : irrigation system (SDrI and DrI); ${ }^{3} \mathrm{RDI}$ : Regulated deficit irrigation (Control, 70 and 100-40 \% ETc). ${ }^{4}$ UEP: coefficient use in effective precipitation (50 and $100 \%$ CA).. ${ }^{4}$ UEP: coefficient use in effective precipitation (50 and $100 \%$ CA). ${ }^{5 T A}$ : total acidity. ${ }^{6}$ TSS:

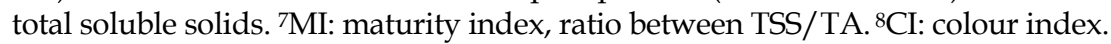

by exposure to light (Ruiz et al., 2005). This exposure to light in fruits from the RDI treatment is related to a significant reduction in the vegetative growth of the trees during fruit development, implying a high exposure of fruits to the light. Similar trends were observed in peach fruits under RDI (Gelly et al., 2003; Buendía et al., 2008).

Significant differences were observed resulting from seasonality in all the fruit quality variables analysed (Table 7). However, values were within the range considered optimal according to the standards established by González-Sicilia (1968).

\section{Conclusions and future research}

Efficient irrigation systems management at the farm level appears to be a very important factor in irrigated agriculture and, given the competition for water resources with other sectors, is a key issue in terms of the economic and environmental sustainability of agriculture. In general, surface and pressurized irrigation systems can attain a reasonable level of efficiency, when they are well designed, adequately operated and appropriately selected for specific conditions. 
Subsurface drip irrigated leads to higher fruit production and water use efficiency and regulated deficit irrigation also provides savings in irrigation water without reducing yield. Thus, both subsurface drip systems and water stress at certain phenological stages of the crop have been demonstrated as a useful tool to improve irrigation management and maintain sustainable production levels at the field scale under arid and semi-arid conditions. Moreover, highly stressful deficit irrigation should not be applied during flowering or fruit-growth periods, in order to ensure yield.

In addition, it is important to emphasize the importance on the use of effective rainfall in reducing the volumes of water applied, without affecting either production or fruit quality.

Other potential strategies for future use, such as partial root-zone, drying by irrigating half of the root-zone while the other half is kept under dry soil, alternating irrigation from one half to the other every 2-3 weeks, low-frequency deficit irrigation, or higher water stress all appear to be promising techniques. Further research is needed to analyse the effects of these strategies on yield, nutritional status, fruit quality and water irrigation savings.

\section{References}

Aboukhaled, A.A.; Alfaro, A. \& Smith, M. (1982). Lysimeters. FAO Irrigation and Drainage. paper $\mathrm{N}^{\circ} 39, \mathrm{FAO}$ (Food and Agriculture Organization of the United Nations), Rome.

Allen, R.G.; Pereira, L.S.; Raes, D. \& Smith, M. (1998). Crop evapotranspiration (guidelines for computing crop water requirements). FAO Irrigation and Drainage., paper $\mathrm{N}^{\mathrm{o}} 56, \mathrm{FAO}$ (Food and Agriculture Organization of the United Nations), Rome, Italy

Antunez, A.; Martínez, J.P.; Alfaro, C. \& Alé, M. (2011). Impact of surface and subsurface drip irrigation on yield and quality of "Honey Dew" Melon. Acta Horticulturae, (ISHS), 889, pp. 417-422

ASAE. (2001) ASAE Standard S526.2, JAN01, In: Soil and Water Terminology, ASAE, St.Joseph, Michigan USA

Bogle, C.R.; Hartz, T.K. \& Nuñez. C. (1989). Comparison of subsurface trickle and furrow irrigation on platic-mulched and bare-soil for tomato production. J. Am. Soc. Hort. Sci., 114(1), pp. 40-43

Bonet, L.; Ferrer, P.; Castel, J.R. \& Intrigliolo, D.S. (2010). Soil capacitance sensors and stem dendrometers. Useful tools for irrigation scheduling of commercial orchards?. Spanish Journal of Agricultural Research 8(S2), pp. S52-S65

Boman, B.J.; Zekri, M. \& Stover, E. (2005). Managing salinity in citrus. HortTechnol. 15(1), pp. 108-113

Boss, M.G. (1985). Summary of ICID definitions of irrigation efficiency. Intl. Comm. Irr. And Drainage Bull. 34, pp. 28-31

Bravdo, B. \& Naor, A. (1996). Effect of water regime on productivity and quality of fruit and wine. Acta Horticulturae, 427, pp. 15-26 
Bryla, D.R.; Trout, T.J. \& Ayars, J.E. (2003) Growth and production of young peach trees irrigated by furrow, microjet, surface drip, or subsurface drip systems. HortScience, 38(6), pp.1112-1116

Bucks, D.A.; Erie, L.J.; French, O.F.; Nakayama, F.S. \& Pew, W.D. (1981). Subsurface trickle irrigation management with multiple cropping. Transactions of the ASAE 24(6), pp. 1482-1489

Buendía, B.; Allende, A., Nicolás, E.; Alarcón, J.J. \& Gil, M.I. (2008). Effect of regulated deficit irrigation and crop load on the antioxidant compounds of peaches. J Agric Food Chem, 56, pp. 3601-3608

Bui, W.\& Osgood, R.V. 1(990). Subsurface irrigation trial for alfalfa in Hawaii. In: Proceedings. Third Nat'l Irrigation Symposium, pp. 658-660. St. Joseph, Mich.: ASAE.

Burt, C.; O'Connor, K. \& Ruehr, T. (1998). Fertigation. Irrigation Training and Research Center, California Polytechnic State Univ. San Luis Obispo, CA.

Camp, C.R. (1998). Subsurface drip irrigation: A review. Trans. Amer. Soc Agr. Eng, 41, pp. 1353-1367

Castel, J.R. \& Buj. A. (1990). Response of Salustiana oranges to high frequency deficit irrigation. Irrg. Sci., 11, pp. 121-127

Castel, J.R. \& Buj, A. (1994). Growth and evapotranspiration of young, drip irrigated Clementine trees, Proceedings of International Congress of Citriculture. Seventh meeting of the International Society of Citriculture, 8-13 March 1992 Acireale, Italy 2, pp. 651-656

Chartzoulakis, K. \& Bertaki, M. (2001). Towards Sustainable Water Use on Mediterranean Islands: Addressing Conflicting Demands and Varying Hydrological, Social and Economic Conditions WORK PACKAGE 2 In: Investigation of irrigation methods Recommendations. Deliverable D14 and D22. Project No EVK1 - CT - 2001 - 00092. Funded by the European Commission

Cruse, R.; Wiegand, C.L. \& Swason. W.A. (1982). The effect of rainfall and irrigation management on citrus juice quality in Texas. J. Am. Soc. Hortic. Sci., 107, 767770 .

Devasirvatham, V. (2009). A review of Subsurface Drip Irrigation in Vegetable Production. In: Irrigation Matters Series no 03/09. Cooperative Research Centre for Irrigation Futures. IF Technologies Pty. Ltd. Australia

Domingo, R.; Ruiz-Sánchez, M.C.; Sánchez-Blanco, N.J. \& Torrecillas, A. (1996). Water relations, growth and yield of Fino lemon trees under regulated deficit irrigation. Irrigation Science 16, pp. 115-123

Ebel, R.C.; Proebsting, E.L. \& Evans, R.G. (1995). Deficit irrigation to control vegetative growth in apple and monitoring fruit growth to schedule irrigation. HortScience, 30, pp. 1229-1232

Eliades, G. (1994). Response of grapefruit to different amounts of water apllied by drippers and minisprinklers. Acta Horticulturae, 365, pp. 129-146

El-Otmani, M.; Ait-Oubahou, A.; El-Hassainate, F.; Kaanane, A. \& Lovatt, C.J. (2004). Effect of Gibberellic acid, urea and $\mathrm{KNO}_{3}$ on yield and on composition and nutritional quality of clementine mandarin fruit juice. Acta Horticulturae (ISHS), 2, pp. 149157 
Emblenton, T.W.; Reitz, H.J. \& Jones, W.W. (1973). Citrus fertilization. In: Citrus Industry. Reuther W (Ed) 3, pp. 122-181

Fereres, E. \& Soriano, M.A. (2007). Deficit irrigation for reducing agricultural water use. Journal of Experimental Botany, 58, pp. 147-159

Fernández, J.E.; Díaz-Espejo, A.; Infante, J.M.; Durán, P.; Palomo, M.J.; Chamorro, V.; Girón, I.F. \& Villagarcía, L. (2006). Water relations and gas exchange in olive trees under regulated deficit irrigation and partial rootzone drying. Plant and Soil, 284, pp. 273291

García-Tejero, I. (2010). Deficit irrigation for sustainable Citrus cultivation in Guadalquivir river basin. Ph. D. Thesis. Universidad de Sevilla, Spain 285 pp.

García-Tejero, I.; Durán Zuazo, V.H.; Jiménez Bocanegra, J.A. \& Muriel Fernández, J.L. (2011). Improved water-use efficiency by déficit irrigation programmes: Implications for saving water in citrus orchards. Scientia Horticulturae 128, pp. 274282

Gelly, M.; Recasens, I.; Mata, M.; Arbones, A.; Rufat, J.; Girona, J. \& Marsal, J. (2003). Effects of water deficit during stage II of peach fruit development and postharvest on fruit quality and ethylene production. J Hort Sci Biotechnol, 78, pp. 324-330

Ginestar, C. \& Castel, J.R. (1996). Responses of young Clementine citrus trees to water stress during Different phenological periods. Journal of Horticultural Science, 71, pp. 551559

Goldhamer, D.A. \& Beede, R.H. (2004). Regulated deficit irrigation effects on yield, nut quality and water-use efficiency of mature pistachio trees. Journal of Horticultural Science and Biotechnology, 79, pp. 538-545

Goldhamer, D.A. \& Salinas, M. (2000). Evaluation of regulated deficit irrigation on mature orange trees grown under high evaporative demand. In: Proceedings of the International Society of Citriculture, IX Congress. Orlando, FL: ISC, pp. 227231

Goldhamer, D.A. \& Viveros, M. (2000). Effects of preharvest irrigation cut off durations and postharvest water deprivation on almond tree performance. Irrigation Science, 19, pp. 125-131

Goldhamer, D.A.; Viveros, M. \& Salinas, M. (2006). Regulated deficit irrigation in almonds: effects of variations in applied water and stress timing on yield and yield components. Irrigation Science, 24, pp. 101-114

González-Altozano, P. \& Castel, J.R. (1999). Regulated deficit irrigation in Clementina de Nules' citrus trees. I. Yield and fruit quality effects. Journal of Horticultural Science and Biotechnology 74, pp. 706-713

González-Sicilia, E. (1968). In: El cultivo de los agrios. 3rd. edición.Bello (Ed). Valencia

Grattan, S.R.; Schwankl, L. J. \& Lanini, W.T. (1988). Weed control by subsurface drip irrigation. Calif. Agric. 42(3), pp. 22-24

Hutmacher, R.B.; Phene, C.J.; Davis, K.R.; Vail, S.S.; Kerby, T.A.; Peters, M.; Hawk, C.; Keeley, A.M.; Clark, D.A.; Ballard, D. \& Hudson, N. (1995). Evapotranspiration, fertility management for subsurface drip Acala and Pima cotton. In: Proc. 5th Int'l Microirrigation Congress, pp. 147-154. St. Joseph, Mich.: ASAE 
Ibrahim, A.M. \& Abd El-Samad, G.A. (2009). Effect of different irrigation regimes and partial substitution of N-Mineral by organic manures on water use, growth and productivity of Pomegranate Trees. European Journal of Scientific Research, 38(2), pp. 199-218. ISSN 1450-216X

Keller, J. \& Karmelli, D. (1974). Trickle irrigation design parameters. Transactions of the ASAE 17, pp. 678-684

Koo, R.C.J. \& Smajstrla. A.G. (1985). Effects of trickle irrigation and fertigation on fruit production and juice porduction and juice quality of 'Valencia' orange. Proc. Fla. State Hort. Soc., 97, pp. 8-10

Ladaniya, M. (2008). Fruit quality control, evaluation and analysis. In Citrus fruit: biology, technology and evaluation, pp. 475-500. (Ed Elsevier Academic Press., San Diego CA, USA

Lamm, F.R. \& Camp, C.R. (2007). Subsurface drip irrigation. Microirrigation for crop production design, operation and management, Lamm, F.R., Ayars, J.E., and Nakayama, F.S. (Eds.) Elsevier, pp: 473-551

Legaz, F. \& Primo-Millo, E. (1988). In: Guidelines for Citrus fertilization. Technical Report, Department of the Agriculture, Fish and Food of the Valencian Government, Valencia, Spain, No 5-88 (In Spanish)

López, G:; Rabones, A.; del Campo, J.; Mata, M.; Vallverdú, X.; Girona, J. \& Marsal, J. (2008). Response of peach trees to regulated deficit irrigation during stage II of fruit development and summer pruning. Spanish Journal of Agricultural Research, 6, pp. 479-491

McCarthy, M.G.; Loveys, B.R.; Dry, P.R. \& Stoll, M. (2002). Regulated deficit irrigation and partial rootzone drying as irrigation management techniques for grapevines. In: Deficit irrigation practices, FAO Water Reports No. 22. Rome, Italy: FAO, pp. $79-87$

MARM. (2010). Ministry of Environment, rural and marine. Agricultural Report

Martínez, J.M.; Bañuls, J.; Quiñones, A.; Martín, B.; Primo-Millo, E. \& Legaz, F. (2002). Fate and transformations of $15 \mathrm{~N}$ labelled nitrogen applied in spring to Citrus trees. Journal of Horticultural Science \& Biotechnology 77, pp. 361-367

Mitchell, P.D. \& Chalmers, D.J. (1982). The effect of reduced water supply on peach tree growth and yields. Journal of the American Society of Horticultural Science 107, pp. 853-856

Mitchell, P.D.; van den Ende, B.; Jerie, P.H. \& Chalmers, D.J. (1989). Response of 'Bartlett' pear to withholding irrigation, regulated deficit irrigation, and tree spacing. Journal of the American Society of Horticultural Science, 114, pp. 15-19

Moriana, A.; Orgaz, F.; Pastor, M. \& Fereres, E. (2003). Yield responses of mature olive orchard to water deficits. Journal of the American Society for Horticultural Science, 123, pp. $425-431$

Ollier, C; Cardoso, F. \& DrInu, M. (2009). Summary results of the EU-27 orchard survey In: Statistics in Focus, Agriculture and Fisheries. Eurostat. European Commission.

Oron, G.; DeMalach, Y. \& Hoffman, Z. (1989). Subsurface trickle irrigation of alfalfa with treated wastewater. In: Progress Report. Israel: Ben Gurion Univ., Institute of Desert Research. 
Peng Y.H. \& Rabe. E. (1998). Effect of differing irrigations regimes on fruit quality, yield, fruit size and net $\mathrm{CO}_{2}$ assimiliation on "Mihbowase" satsuma. J. Hort. Sci. Biotecnology, 73(2), pp. 229-234

Phene, C.J. (1995). The sustainability and potential of subsurface drip irrigation. In: Proc. 5th Int'l Microirrigation Congress, pp. 359-367. St. Joseph, Mich. ASAE.

Phene, C.J.; Davis, K.R. \& McCormick, R.L. (1987). Evapotranspiration and irrigation scheduling of drip irrigated cantaloupes. ASAE Paper No. 87-2526. St. Joseph, Mich.: ASAE

Phene, C.J.; Hutmacher, R.B. \& Ayars, J.E. (1992). Subsurface drip irrigation: Realizing the full potential. In: Proc. of Conference on Subsurface Drip Irrigation, pp. 137-158. CATI Publication 921001. Fresno, Calif.: California State Univ. USA

Pérez-Sarmiento F.; Alcobendas, R; Mounzer, O; Alarcón, J. \& Nicolás, E. (2010). Effects of regulated deficit irrigation on physiology and fruit quality in apricot trees. Spanish Journal of Agricultural Research, 8(S2), pp. S86-S94

Romero, P.; Botia, P. \& Garcia, F. (2004). Effects of regulated deficit irrigation under subsurface drip irrigation conditions on water relations of mature almond trees. Plant and Soil, 260, pp. 155-168

Ruiz-Sánchez, M.C.; Torrecillas, A.; Pérez-Pastor, A. \& Domingo, R. (2000). Regulated deficit irrigation in apricot trees. Acta Horticulturae, 537, pp. 759-766.

Sánchez-Blanco, M.J.; Torrecillas, A.; León, A. \& del Amor, F. (1989). The effect of different irrigation treatments on yield and quality of Verna lemon. Plant and Soil, 120, pp. 299-302

Scandella, D.; Kraeutler, E. \&V’enien, S. (1997). Anticiper la qualit’e gustative des p^eches et nectarines. Infos CTIFL129, pp. 16-19 (In French).

Schumann, A.W.; Syvertsen, J.P. \& Morgan, K.T. (2009) Implementing Advanced Citrus Production Systems in Florida-Early Results. Proc Fal State Hort Soc 122, pp. 108113

Sne, M. (2006). Micro irrigation in arid and semi-arid regions. In Kulkarni SA (Ed.) Guidelines for planning and design. In: International Commission on Irrigation and Drainage. New Delhi, India

Sterret, S.B.; Ross, B.B.\& Savage, C.P. (1990). Establishment and yield of asparagus as influenced by planting and irrigation method. J. American Soc. Hort. Sci., 115(1), pp. 29-33

Quiñones, A.; Martínez-Alcántara, B. \& Legaz, F. (2007) Influence of irrigation system and fertilization management on seasonal Distribution of $\mathrm{N}$ in the soil profile and on $\mathrm{N}$ uptake by citrus trees. Agri Ecosyst Environ 122, pp. 399-409

Quiñones, A.; Martínez-Alcántara, B.; San-Francisco, S.; García-Mina, J.M. \& Legaz, F. (2011), Methyl Xanthine as a potential alternative to Gibberellic acid in enhancing fruit set and quality in clementine citrus trees in Spain. Experimental Agricultural, 47(1), pp. 159-171, doi:10.1017/S0014479710000906.

Tognetti, R.; d'Andria, R.; Morelli, G. \& Alvino, A. (2005). The effect of deficit irrigation on seasonal variations of plant water use in Olea europaea L. Plant and Soil, 273, pp. 139155 
Tognetti, R.; d'Andria, R.; Lavini, A. \& Morelli. G. (2006). The effect of deficit irrigation on crop yield and vegetative development of Olea europaea L. (cvs. Frantoio and Leccino). European Journal of Agronomy, 25, 356-364

Velez, J.E.; Intrigliolo, D.S. \& Castel, J.R. (2007) Scheduling deficit irrigation of citrus trees with maximum daily trunk shrinkage agricultural water management 90, pp. 197204

Wallace, J.S. \& Batchelor, C.H. (1997). Managing water resources for crop production, Philos. Trans. R. Soc. London Ser. B. 352, pp. 937-947

Yazar, A.; Sezen, S.M. \& Sesveren S. (2002). LEPA and trickle irrigation of cotton in the Southeast Anatolia. Project (GAP) area in Turkey. Agricultural Water Management, 54, pp. $189-203$ 


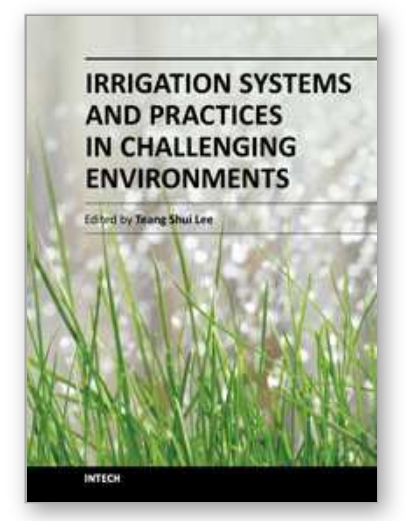

\author{
Irrigation Systems and Practices in Challenging Environments \\ Edited by Dr. Teang Shui Lee
}

ISBN 978-953-51-0420-9

Hard cover, 370 pages

Publisher InTech

Published online 28, March, 2012

Published in print edition March, 2012

The book Irrigation Systems and Practices in Challenging Environments is divided into two interesting sections, with the first section titled Agricultural Water Productivity in Stressed Environments, which consists of nine chapters technically crafted by experts in their own right in their fields of expertise. Topics range from effects of irrigation on the physiology of plants, deficit irrigation practices and the genetic manipulation, to creating drought tolerant variety and a host of interesting topics to cater for the those interested in the plant water soil atmosphere relationships and agronomic practices relevant in many challenging environments, more so with the onslaught of global warming, climate change and the accompanying agro-meteorological impacts. The second section, with eight chapters, deals with systems of irrigation practices around the world, covering different climate zones apart from showing casing practices for sustainable irrigation practices and more efficient ways of conveying irrigation waters - the life blood of agriculture, undoubtedly the most important sector in the world.

\title{
How to reference
}

In order to correctly reference this scholarly work, feel free to copy and paste the following:

Ana Quiñones, Carolina Polo-Folgado, Ubaldo Chi-Bacab, Belén Martínez-Alcántara and Francisco Legaz (2012). Water Productivity and Fruit Quality in Deficit Drip Irrigated Citrus Orchards, Irrigation Systems and Practices in Challenging Environments, Dr. Teang Shui Lee (Ed.), ISBN: 978-953-51-0420-9, InTech, Available from: http://www.intechopen.com/books/irrigation-systems-and-practices-in-challenging-environments/waterproductivity-and-fruit-quality-in-deficit-drip-irrigated-citrus-orchards

\section{INTECH}

open science | open minds

\section{InTech Europe}

University Campus STeP Ri

Slavka Krautzeka 83/A

51000 Rijeka, Croatia

Phone: +385 (51) 770447

Fax: +385 (51) 686166

www.intechopen.com

\section{InTech China}

Unit 405, Office Block, Hotel Equatorial Shanghai

No.65, Yan An Road (West), Shanghai, 200040, China

中国上海市延安西路65号上海国际贵都大饭店办公楼405单元

Phone: +86-21-62489820

Fax: $+86-21-62489821$ 
(C) 2012 The Author(s). Licensee IntechOpen. This is an open access article distributed under the terms of the Creative Commons Attribution 3.0 License, which permits unrestricted use, distribution, and reproduction in any medium, provided the original work is properly cited. 